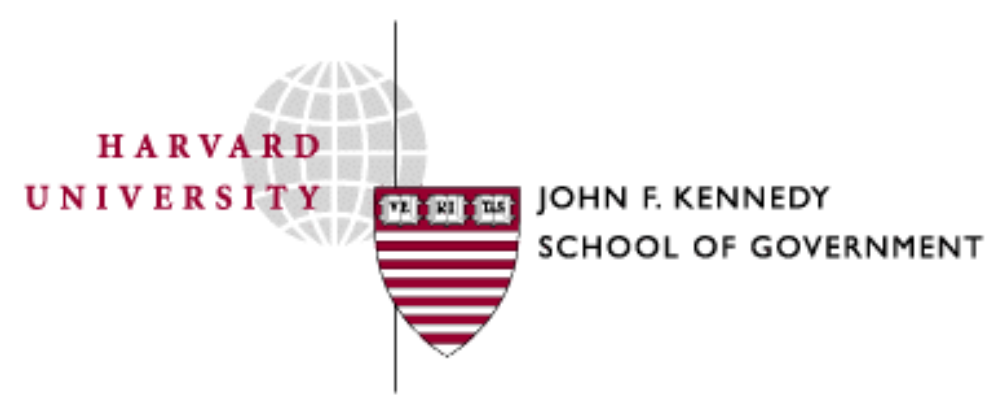

Faculty Research Working Papers Series

\title{
Industrial Policy for the Twenty-First Century
}

\section{Dani Rodrik}

November 2004

RWP04-047 belongs to the author(s). Papers may be downloaded for personal use only. 


\title{
INDUSTRIAL POLICY FOR THE TWENTY-FIRST CENTURY*
}

\author{
Dani Rodrik \\ Harvard University \\ John F. Kennedy School of Government \\ 79 Kennedy Street \\ Cambridge, MA 02138 \\ (617) 495-9454 \\ Fax: (617) 496-5747 \\ E-mail: dani_rodrik@harvard.edu \\ http://www.ksg.harvard.edu/rodrik/
}

This version

September 2004

* This paper has been prepared for UNIDO. I am grateful to Francisco Sercovich for his guidance. I am also grateful to Robert Lawrence, Lant Pritchett, Andres Rodriguez-Clare, Andres Velasco, and especially Ricardo Hausmann and Roberto Unger for conversations over the last few years that led to the development of these ideas. None of these individuals should be held responsible for the views expressed here. I also thank Magali Junowicz for expert research assistance. 


\section{$\underline{\text { I. Introduction }}$}

Once upon a time, economists believed the developing world was full of market failures, and the only way in which poor countries could escape from their poverty traps was through forceful government interventions. Then there came a time when economists started to believe government failure was by far the bigger evil, and that the best thing that government could do was to give up any pretense of steering the economy. Reality has not been kind to either set of expectations. Import substitution, planning, and state ownership did produce some successes, but where they got entrenched and ossified over time, they led to colossal failures and crises. Economic liberalization and opening up benefited export activities, financial interests, and skilled workers, but more often than not, they resulted in economy-wide growth rates (in labor and total factor productivity) that fell far short of those experienced under the bad old policies of the past.

Few people seriously believe any more that state planning and public investment can act as the driving force of economic development. Even economists of the left share a healthy respect for the power of market forces and private initiative. At the same time, it is increasingly recognized that developing societies need to embed private initiative in a framework of public action that encourages restructuring, diversification, and technological dynamism beyond what market forces on their own would generate. Perhaps not surprisingly, this recognition is now particularly evident in those parts of the world where market-oriented reforms were taken the farthest and the disappointment about the outcomes is correspondingly the greatest—notably in Latin America. ${ }^{1}$

\footnotetext{
${ }^{1}$ See for example de Ferranti et al. (2002). This is a report put out by the Latin America and Caribbean department of the World Bank. It is cognizant of the need to adopt some kind of industrial policies in order to generate technological dynamism in the region.
} 
Therefore we now confront a rare historic opportunity. The softening of convictions on both sides presents an opening to fashion an agenda for economic policies that takes an intelligent intermediate stand between the two extremes cited above. Market forces and private entrepreneurship would be in the driving seat of this agenda, but governments would also perform a strategic and coordinating role in the productive sphere beyond simply ensuring property rights, contract enforcement, and macroeconomic stability.

This paper is a contribution to one component of such an agenda, focusing on policies for economic restructuring. Such policies have been called in the past "industrial policies," and for lack of a better term, I will continue to call them as such. I will use the term to apply to restructuring policies in favor of more dynamic activities generally, regardless of whether those are located within industry or manufacturing per se. Indeed, many of the specific illustrations in this paper concern non-traditional activities in agriculture or services. There is no evidence that the types of market failures that call for industrial policy are located predominantly in industry, and there is no such presumption in this paper.

The nature of industrial policies is that they complement—opponents would say "distort" - market forces: they reinforce or counteract the allocative effects that the existing markets would otherwise produce. The objective of this paper is to develop a framework for conducting industrial policy that maximizes its potential to contribute to economic growth while minimizing the risks that it will generate waste and rent-seeking.

I shall argue that in order to achieve this objective we need to think of industrial policy in a somewhat different light than is standard in the literature. The conventional approach to industrial policy consists of enumerating technological and other externalities and then targeting policy interventions on these market failures. The discussion then revolves around the 
administrative and fiscal feasibility of these policy interventions, their informational requirements, their political-economy consequences, and so on. I start also from generic market failures, but then I take it as a given that the location and magnitude of these market failures is highly uncertain. A central argument of this paper is that the task of industrial policy is as much about eliciting information from the private sector on significant externalities and their remedies as it is about implementing appropriate policies. The right model for industrial policy is not that of an autonomous government applying Pigovian taxes or subsidies, but of strategic collaboration between the private sector and the government with the aim of uncovering where the most significant obstacles to restructuring lie and what type of interventions are most likely to remove them. Correspondingly, the analysis of industrial policy needs to focus not on the policy outcomes - which are inherently unknowable ex ante-but on getting the policy process right. We need to worry about how we design a setting in which private and public actors come together to solve problems in the productive sphere, each side learning about the opportunities and constraints faced by the other, and not about whether the right tool for industrial policy is, say, directed credit or R\&D subsidies or whether it is the steel industry that ought to be promoted or the software industry.

Hence the right way of thinking of industrial policy is as a discovery process-one where firms and the government learn about underlying costs and opportunities and engage in strategic coordination. The traditional arguments against industrial policy lose much of their force when we view industrial policy in these terms. For example, the typical riposte about governments' inability to pick winners becomes irrelevant. Yes, the government has imperfect information, but as I shall argue, so does the private sector. It is the information externalities generated by ignorance in the private sector that creates a useful public role-even when the public sector has 
worse information than the private sector. Similarly, the idea that governments need to keep private firms at arms' length to minimize corruption and rent-seeking gets turned on its head. Yes, the government needs to maintain its autonomy from private interests. But it can elicit useful information from the private sector only when it is engaged in an ongoing relationship with it—a situation that has been termed "embedded autonomy" by the sociologist Peter Evans (1995).

It is innovation that enables restructuring and productivity growth. A second key theme of this paper is that innovation in the developing world is constrained not on the supply side but on the demand side. That is, it is not the lack of trained scientists and engineers, absence of R\&D labs, or inadequate protection of intellectual property that restricts the innovations that are needed to restructure low-income economies. Innovation is undercut instead by lack of demand from its potential users in the real economy - the entrepreneurs. And the demand for innovation is low in turn because entrepreneurs perceive new activities to be of low profitability.

I will discuss the reasons for this conjecture in greater detail in section II, but a useful analogy to keep in mind is with education and human capital. For quite a while, policy makers thought that the solution to poor human capital lay in improving the infrastructure of schoolingmore schools, more teachers, more textbooks, and more access to all three. These interventions did increase the supply of schooling, but when the results were in, it became evident that the increase in schooling did not produce the productivity gains that were anticipated (Pritchett 2004). The reason is simple. The real constraint was the low demand for schooling - that is, the low propensity to acquire learning - in environments where the absence of economic opportunities depress the return to education. Similarly, an expansion of an economy's scientific and technological capacity will not endow it with the needed productive dynamism unless there 
is adequate demand for innovation by the business sector.

The plan of the paper is as follows. In section II, I review the main arguments in favor of industrial policy, emphasizing the pervasive role of market failures that result in the underprovision of entrepreneurship in pursuit of structural change. The standard rationale for industrial policy is technological externalities, either static or dynamic in the form of learningby-doing that is external to firms. I will emphasize two other market failures which I believe are far more rampant: information externalities entailed in discovering the cost structure of an economy, and coordination externalities in the presence of scale economies. In section III, I turn to the institutional requirements for an effective industrial policy. I will argue here that getting the institutional setting right, with an adequate balance between autonomy and embeddedness on the part of government officials, is far more important than worrying about the precise policy instruments to be deployed. I will also provide some architectural and design guidelines for institutionalizing industrial policies and describe an illustrative range of programs. In section IV, I discuss existing industrial policy programs and evaluate them in light of the foregoing discussion. Unlike what is commonly believed, the last two decades have not seen the twilight of industrial policy. Instead, incentives and subsidies have been refocused on exports and direct foreign investment, in the belief (largely unfounded, as it turns out) that these activities are the source of significant positive spillovers. Therefore, the challenge in most developing countries is not to rediscover industrial policy, but to redeploy it in a more effective manner. Finally, section $\mathrm{V}$ asks whether the practice of industrial policy remains feasible under today's international rules of the game. I discuss the range of constraints that are embodied in multilateral, regional, and bilateral agreements. I emphasize that most of these constraints — with the significant exception of the WTO Agreements on Subsidies and TRIPS - are either voluntary 
or do not bind in a significant way. What stands in the way of coherent industrial policy is the willingness of governments to deploy it, not their ability to do so.

\section{Why Industrial Policy?}

In an important article published in the American Economic Review, Jean Imbs and Romain Wacziarg (2003) examined the patterns of sectoral concentration and diversification in a large cross-section of countries. They uncovered an important regularity in their data. As poor countries get richer, sectoral production and employment become less concentrated and more diversified. And this process goes on until relatively late in the process of development. It is only after countries reach roughly the level of Ireland's income that production patterns start to become more concentrated. If sectoral concentration is graphed against income per capita, one therefore obtains a U-shaped curve. Imbs and Wacziarg stress the robustness of their finding:

"In fact, our result is an extremely robust feature of the data. The nonmonotonicity holds above and beyond the well-known shift of factors of production from agriculture to manufacturing and on to services - in particular, the U-shaped pattern is present when focusing only on manufactured goods. It is valid whether a sector's size is measured by its share in total employment or whether it is measured by shares in value added. It holds within countries through time as well as in a pure cross section, for a variety of levels of disaggregation and data sources. The estimated turnaround point occurs quite late in the development process and at a surprisingly robust level of income per capita. Thus, increased sectoral specialization, although a signifcant development, applies only to high-income economies. Countries diversify over most of their development path." (Imbs and Wacziarg 2003, 64)

What is significant about this finding from our standpoint is that it goes against the standard intuition flowing from the principle of comparative advantage. The logic of comparative advantage is one of specialization. It is specialization that raises overall productivity in an economy that is open to trade. Those who associate under-development with inadequate exposure to international markets generally imply_-although this is often left 
unstated - that specialization according to comparative advantage is an essential ingredient of development.

Imbs and Wacziargs' findings suggest otherwise. Whatever it is that serves as the driving force of economic development, it cannot be the forces of comparative advantage as conventionally understood. The trick seems to be to acquire mastery over a broader range of activities, instead of concentrating on what one does best. This point is further underscored by the detailed analysis of export data by Klinger and Lederman (2004), who show that the number of new export products also follows an inverted U-curve in income.

The next question is what determines why some countries are better able to develop this mastery than others. Why do some economies find it easier to diversify from traditional to nontraditional products and keep the progression rolling along? We get a better handle on this question by turning it on its head and asking why diversification is not a natural process and how it can be easily derailed.

Imagine an economy with a well-behaved government that has done its Washington Consensus homework. Macroeconomic instability is not a problem, market interventions are minimal, trade restrictions are few and far in between, property rights are protected, and contracts are enforced. Will the type of entreprenurship that is required to build up nontraditional activities be amply supplied? There are good reasons to believe that the answer is no. Most fundamentally, market prices cannot reveal the profitability of resource allocations that do not yet exist. (In general equilibrium theory, this is finessed by assuming that markets are "complete" and there is a price for everything.) The returns from investing in non-traditional activities are therefore hazy at best. It is possible to state this difficulty in the language of conventional economics, and in what follows I will discuss two key "externalities" that blunt the 
incentives for productive diversification: information externalities and coordination externalities. Both are reasons to believe that diversification is unlikely to take place without directed government action.

Consider a recent example taken from the pages of the New York Times. Taiwan has traditionally grown and exported sugar, an industry that has recently fallen into hard times due to low international prices and other reasons. What should now be grown in the fields to replace the sugarcane that is the source of income for many farmers? In many countries, the result would have been a depressed rural sector, increasingly indebted farm households, and a drag on the economy. In Taiwan, the response has been a $\$ 65$ million government investment program to develop a world-class orchid industry. The government pays for a genetics laboratory, quarantine site, shipping and packing areas, new roads, water and electrical hookups for privately-owned greenhouses, and an exposition hall—in fact everything except for the cost of the greenhouses. It also provides low-interest credit to farmers to help them build the greenhouses. $^{2}$

This is admittedly an extreme example, and the Taiwanese experiment with orchids may yet turn out to be an expensive flop. But I will suggest below that this vignette illustrates a general principle rather than an exception. Most significant instances of productive diversification are indeed the result of concerted government action and of public-private collaboration. This is as much true of Latin America as it is of East Asia.

\section{$\underline{\text { Information externalities }}$}

Diversification of the productive structure requires “discovery" of an economy's cost structure - i.e., discovery of which new activities can be produced at low enough cost to be

\footnotetext{
${ }^{2}$ This information is taken from New York Times, August 24, 2004, p. A1.
} 
profitable. Entrepreneurs must experiment with new product lines. They must tinker with technologies from established producers abroad and adapt them to local conditions. This is the process that Ricardo Hausmann and I called "self discovery" (Hausmann and Rodrik 2004), and which seems integral to the stylized facts about development uncovered by Imbs and Wacziarg (2003).

When we put ourselves in the shoes of an entrepreneur engaged in cost discovery, we immediately see the key problem: this is an activity that has great social value and yet is very poorly remunerated. If the entrepreneur fails in his venture, he bears the full cost of his failure. If he is successful, he has to share the value of his discovery with other producers who can follow his example and flock into the new activity. In the limit, with free entry, entrepreneurship of this kind produces private costs and social gains. It is no great surprise that low-income countries are not teeming with entrepreneurs engaged in self-discovery.

Note that the kind of discovery that matters in this context differs from innovation and $\mathrm{R} \& \mathrm{D}$ as these terms are commonly understood. What is involved is not coming up with new products or processes, but "discovering" that a certain good, already well established in world markets, can be produced at home at low cost. This may involve some technological tinkering to adapt foreign technology to domestic conditions, but this tinkering rarely amounts to something that is actually patentable and therefore monopolizable. The entrepreneurs who figured out that Colombia was good terrain for cut flowers, Bangladesh for t-shirts, Pakistan for soccer balls, and India for software generated large social gains for their economies, but could keep very few of these gains to themselves. The policy regimes in developing countries have no analogues to the patent system that protects innovation in the advanced countries. 
In Hausmann and Rodrik (2004) we provised some informal evidence to suggest that these features are endemic to the process of economic development. We showed that countries with nearly identical resource and factor endowments specialize in very different types of products, once one looks beyond very broad aggregates such as labor-intensive commodities. Bangladesh exports millions of dollars worth of hats, while Pakistan exports virtually none. Conversely, Pakistan exports tons of soccer balls, while Bangladesh lacks a significant soccer ball industry. At a different level of income, Korea is a world power in microwave ovens and barely exports any bicycles, while the pattern is reversed in Taiwan. It is impossible to ascribe these patterns of specialization to comparative advantage. They are more likely the result of random self-discovery attempts, followed by imitative entry. Indeed, we showed how whole industries often arise out of the experimental efforts of lone entrepreneurs. Garments in Bangladesh, cut flowers in Colombia, IT in India, and salmon in Chile (with a state entity acting as the entrepreneur in the last case) are some of the better documented cases. In each one of these cases, imitative entry through managerial and labor turnover, was the key mechanism that enabled industry growth (while undercutting the rents of incumbent entrepreneurs). The orchid case in Taiwan provides an example in the earlier stages of development. It is unlikely that a private farmer would have had the incentive to invest in orchids in the absence of good information that the effort would have been profitable. Once the industry is established by the state, the number of private greenhouses will surely take off if the early investments pay off. Klinger and Lederman (2004) have recently provided more systematic evidence on the market failures that restrict self-discovery. These authors show that their measure of selfdiscovery in a country (the number of new products being exported) is positively associated with the height of entry barriers: the more costly are government regulations that impede business 
formation, the higher the rate of self-discovery in exports. This somewhat counterintuitive result can only be understood in terms of the ideas considered here: easy of entry facilitates imitation, undercuts the rents to entrepreneurship in self-discovery, and therefore reduces the level of selfdiscovery.

The first-best policy response to the informational externalities that restrict self-discovery is to subsidize investments in new, non-traditional industries. As a practical matter, it is difficult to implement such a subsidy. The difficulty in monitoring the use to which the subsidy would be put — an investor might as well use it for purposes that provide direct consumption benefitsrenders the first-best policy intervention largely of theoretical interest. ${ }^{3}$ In Hausmann and Rodrik (2003), we recommend generically a carrot-and-stick strategy. Since self-discovery requires rents to be provided to entrepreneurs, one side of the policy has to take the form of a carrot. This can be a subsidy of some kind, trade protection, or the provision of venture capital. Note that the logic of the problem requires that the rents be provided only to the initial investor, not to copycats. To ensure that mistakes are not perpetuated and bad projects are phased out, these rents must in turn be subject either to performance requirements (for example, a requirement to export), or to close monitoring of the uses to which they are put. In other words, there has to be a stick to discipline opportunistic action by the recipient of the subsidy. East Asian industrial policies have typically had both elements (see the classic discussion in Amsden 1989 and Wade 1990). Latin American industrial policies typically have used too much of the carrot, and too little of the stick, which explains why Latin America has ended up with much inefficiency alongside some world-class industries.

\footnotetext{
${ }^{3}$ The situation is somewhat analogous with respect to technological externalities that flow from R\&D. In this case, the first-best is an R\&D subsidy. But advanced countries provide patent protection, which is second-best, to stimulate R\&D.
} 
A subtle but important point here is that that even under the optimal incentive program, some of the investments that are promoted will turn out to be failures. This is because optimal cost discovery requires equating the social marginal cost of investment funds to the expected return of projects in new areas. The realized return on some of the projects will necessarily be low or negative, to be compensated by the high return on the successes. The stunning success that Fundacion Chile - a public agency — achieved with salmon can pay for many subsequent mistakes. ${ }^{4}$ In fact, if there are no or few failures, this could even be interpreted as a sign that the program is not aggressive or generous enough. However, a good industrial policy will prevent such failures from gobbling up the economy's resources indefinitely, and it will ensure that they are phased out. The trick for the government is not to pick winners, but to know when it has a loser.

\section{$\underline{\text { Coordination externalities }}$}

Many projects require simultaneous, large-scale investments to be made in order to become profitable. Return, for example, to the orchid case in Taiwan. An individual producer contemplating whether to invest in a greenhouse needs to know that there is an electrical grid he can access nearby, irrigation is available, the logistics and transport networks are in place, qurantine and other public health measures have been taken to protect his plants from his neighbors' pests, and his country has been marketed abroad as a dependable supplier of highquality orchids. All of these services have high fixed costs, and are unlikely to be provided by private entities unless they have an assurance that there will be enough greenhouses to demand

\footnotetext{
${ }^{4}$ Fundacion Chile is a public agency that was created by funds donated by ITT. It began experimenting with salmon in the second half of the 1970s and set up a firm in the early 1980s using a technology adapted from that in Norway and Scotland. The company was eventually sold to a Japanese fishing company. Before Fundacion Chile's efforts, Chile exported barely any salmon. The country is now one of the world's biggest salmon exporters. See Agosin (1999).
} 
their services in the first place. This is a classic coordination problem. Profitable new industries can fail to develop unless upstream and downstream investments are coaxed simultaneously. The Taiwanese government's investments upstream aim precisely to overcome this obstacle. More generally, coordination failures can arise whenever new industries exhibit scale economies and some of the inputs are non-tradable (or require geographic proximity) (Rodrik 1996). Big push models of development are based on the idea that such features are predominant in low-income environments. The cluster approach to development represents a narrower version of the same idea, focussing on the development of specific sectors such as tourism, pharmaceuticals, or bio-tech. In all these versions, the coordination failure model places a premium on the ability to coordinate the investment and production decisions of different entrepreneurs. Sometimes, when the industry in question is highly organized and the benefits of the needed investments can be localized, this coordination can be achieved within the private sector, without the government playing a specific role. But more commonly, with a nascent industry and a private sector that has yet to be organized, a government role will be required.

An interesting but often neglected aspect of coordination failures is that they do not necessitate subsidization, and overcoming them need not be costly to the government budget. In this respect, coordination externalities differ from the information externalities discussed above that do necessitate subsidies of some sort. It is the logic of coordination failures that once the simultaneous investments are made all of them end up profitable. Therefore none of the investors needs to be subsidized ex post, unless there is an additional reason (i.e., a nonpecuniary externality) that such subsidization is required. The trick is to get these investments made in the first place. That can be achieved either by true coordination- "firm A will make this investment if firm B makes this other investment”- or by designing ex ante subsidies that do 
not need to be paid ex post. A implicit bail-out, or an investment guarantee is an example of such an ex-ante subsidy. Suppose the government guarantees that the investor will be made whole if the project fails. This induces the investor to proceed with the investment. If the project succeeds, the investor does not need any cash transfer from the government, and no subsidies are paid out. This is one way in which some industries got started out in South Korea, as the regime of President Park gave implicit investment guarantees to leading Chaebols that invested in new areas. On the other hand, this type of policy is obviously open to moral hazard and abuse; for a while it was common to blame the Asian financial crisis on the "cronyism" engendered by these implicit bail-out guarantees.

As Andres Rodriguez-Clare (2004) has recently stressed, all industries in principle have the characteristics that could produce clusters. Moreover, many industries can in principle operate at some level in the absence of clusters. This suggests that what needs support is not specific sectors per se, but the type of technologies that have scale or agglomeration economies and would fail to catch on in the absence of support. Simply providing trade protection to a particular sector may not overcome the coordination failure that prevents the adoption of a modern technology, since it increases the profitability of operating without that technology as well. The appropriate policy intervention is focused not on industries or sectors, but on the activity or technology that produces the characterictics of a coordination failure.

Hence, the policies that overcome coordination failure share an important characteristic with those focused on information externalities. Both sets of interventions need to be targeted on activities (a new technology, a particular kind of training, a new good or service), rather than on sectors per se. It is activities that are new to the economy that need support, not those that are already established. 
$\underline{\text { Back to reality }}$

When viewed from the perspective of the discussion above, it is not surprising to observe that industrial restructuring rarely takes place without significant government assistance. Scratch the surface of nontraditional export success stories from anywhere around the world, and you will more often than not find industrial policies, public R\&D, sectoral support, export subsidies, preferential tariff arrangements, and other similar interventions lurking beneath the surface. The role played by such policies in East Asia is well known. What is less well appreciated is how the same holds for Latin America as well.

By way of illustration, Table 1 lists the top five export items (to the United States) of three leading Latin American economies: Brazil, Chile, and Mexico. When one leaves aside traditional commodity exports such as copper and crude oil, it is striking how each of the products on the list has been the beneficiary of preferential support policies. In the case of Brazil, the steel, aircraft, and (to an important extent) shoe industries are all the creation of import substitution policies of the past. High levels of protection (steel and shoes) and public ownership, public R\&D, and subsidized credit (aircraft) were deliberately used to generate rents for entrepreneurs investing in new areas and to build up industrial clusters. In the case of Chile, industrial policies played a huge role in grapes, forestry, and salmon. The role of Fundacion Chile in getting the salmon industry off the ground has been already mentioned. In grapes, there was significant public R\&D in the 1960 s that transformed an industry that was primarily oriented to the local market into a global powerhouse (Jarvis 1994). And in forestry, there is a history of at least 60 years of subsidizing plantations (see Clapp 1995) as well as a big push since 1974 to turn the wood, pulp and paper, and furniture cluster into a major export industry (Agosin 1999). 
Productive diversification in Chile is hardly the result of letting markets run free. In Mexico, the motor vehicles and computer industries are the creation of import-substitution policies (initially), followed by preferential tariff policies under NAFTA. None of these are the result of hands-off policies, or of level playing fields and unadulterated market forces.

Hence the difference between East Asia and Latin America is not that industrial transformation has been state-driven in one and market-driven in the other. It is that industrial policy has not been as concerted and coherent in Latin America as it has been in East Asia, with the consequence that the transformation has been less deeply rooted in the former than it is in the latter.

\section{Institutional arrangements for industrial policy}

In the previous discussion I have linked the need for industrial policy to two key market failures that weaken the entrepreneurial drive to restructure and diversify low-income economies. One has to do with the informational spillovers involved in discovering the cost structure of an economy, and the other has to do with the coordination of investment activities with scale economies. It is tempting to then go on to discuss the list of policy instruments, first-best and second-best, that can overcome these difficulties. But this would overlook two key issues that bedevil the conduct of industrial policy.

First, the public sector is not omniscient, and indeed typically has even less information than the private sector about the location and nature of the market failures that block diversification. Governments may not even know what it is they do not know. Consequently, the policy setting has to be one in which public officials are able to elicit information from the business sector on an ongoing basis about the constraints that exist and the opportunities that are 
available. It cannot be one in which the private sector is kept at arms' length and autonomous bureaucrats issue directives. To use Peter Evans' terminology, industrial policy-making has to be embedded within a network of linkages with private groups.

Second, industrial policy is open to corruption and rent-seeking. Any system of incentives designed to help private investors venture into new activities can end up serving as a mechanism of rent transfer to unscrupulous businessmen and self-interested bureaucrats. The natural response is to insulate policymaking and implementation from private interests, and to shield public officials from close interaction with businessmen. Note how this impulse_- "keep bureaucrats and businessmen distant from each other"- -is diametrically opposed to the previous one arising from the need for information flows.

The critical institutional challenge therefore is to find an intermediate position between full autonomy and full embeddedness. Too much autonomy for the bureaucrats, and you have a system that minimizes corruption, but fails to provide the incentives that the private sector really needs. ${ }^{5}$ Too much embeddedness for the bureaucats, and they end up in bed with (and in the pockets of) business interests. Moreover, we would like the process to be democratically accountable and to carry public legitimacy.

Getting this balance right is so important that it overshadows, in my view, all other elements of policy design. In particular, once the institutional setting is "right," we need to worry considerably less about appropriate policy choice. A first-best policy in the wrong institutional setting will do considerably less good than a second-best policy in an appropriate

\footnotetext{
${ }^{5}$ Some years ago, I compared the effectiveness of six different export subsidy programs around the world, and found, somewhat to my surprise, that the programs with the clearest rules and least opportunity for manipulation by the private sector were not the most effective on the ground. The best functioning programs were those in places like Brazil and South Korea where the bureaucrats were in close interaction with the exporters they were subsidizing. See Rodrik (1995).
} 
institutional setting. Put differently, when it comes to industrial policy specifying the process is more important than specifying the outcome.

Thinking of industrial policy as a "process" has the added benefit that it leaves open the possibility that the actual obstacles to diversification may differ significantly from those hypothesized above. Listening to businessmen without getting captured may reveal that the real problems are not the government's errors of omission (e.g., externalities that have not been internalized), but its errors of commission (e.g., misguided interventions that have increased the cost of doing business). Occasionally, the problems may lie in unexpected areas-for example a quirk in the tax code or a piece of otherwise innocuous legislation. Policy recommendations based on ex-ante reasoning would get it badly wrong in such cases.

These ideas have much in common with the recent literature on institutional innovation, which emphasizes the shortcomings of the hierarchical, principal-agent model of governance in environments of volatility and deep uncertainty (see in particular Sabel 2003, 2004). Solving the problems outlined in the previous section involves social learning - discovering where the information and coordination externalities lie and therefore what the objectives of industrial policy ought to be and how it is to be targeted. In this setting, the principal-agent model, with the government as the principal, the firms as its agent, and an optimal policy which aligns the agents' behavior with the principal's objectives at least cost, does not work very well. What is needed instead is a more flexible form of strategic collaboration between public and private sectors, designed to elicit information about objectives, distribute responsibilities for solutions, and evaluate outcomes as they appear. An ideal industrial policy process operates in an institutional setting of this form. 
As Charles Sabel emphasizes, institutions of learning have to be experimentalist by their nature. Just as discovering underlying costs require entrepreneurial experimentation, discovering the appropriate ways in which restructuring bottlenecks can be overcome needs a trial-and-error approach to policymaking.

These ideas need to be operationalized in order to become useful in practice. The challenge in a paper like this is to give a flavor of how this can be done without falling into the trap of misplaced concreteness and appearing to recommend a one-size-fits all institutional strategy. I proceed in two steps. First, I will discuss some generically desirable architectural features of institutions of industrial policy. Next, I will enumerate some design principles that should inform the formulation of industrial policy. These suggestions occupy an intermediate position between the more abstract ideas discussed above and concrete recommendations on institutional design. ${ }^{6}$

\section{$\underline{\text { Elements of an institutional architecture }}$}

Political leadership at the top. The success of industrial policy often depends on the presence of high-level political support. Fiscal prudence has a champion in the person of a finance minister and sound money has a champion in the person of a central bank governor. Economic restructuring also needs a political advocate who has the ear of the president or prime minister and can stand as equals with other members of the economic cabinet. This serves several purposes. First, it raises the profile of industrial policies and enables problems of economic transformation to receive a hearing at the highest levels of the government. Second, it provides coordination, oversight and monitoring for the bureaucrats and the agencies entrusted

\footnotetext{
${ }^{6}$ These ideas draw on work done in El Salvador and reported in Hausmann and Rodrik (2003b). See also Sabel and Reddy (n.d.) for some suggestions on the architecture of industrial policymaking.
} 
with carrying out industrial policies. If the bureaucrats are to have autonomy, it is critical that their performance be systematically monitored by such a high-level official. Third, it identifies a clear political principal as accountable for the consequences of industrial policies. This political advocate could be a cabinet-level minister, the vice-president (in presidential systems), or even the president himself (as was the case in South Korea under President Park).

Coordination and deliberation council(s). While institutional choices will naturally differ from setting to setting, depending on initial conditions, there is a generic need for coordination or deliberation councils within which the information exchange and social learning, as discussed above, can take place. These are private-public bodies that ought to include relevant groups or their representatives. To avoid the biases of incumbents and insiders, these should go beyond the typical "peak" organizations that include only well organized groups and business associations. They would be the setting in which private-sector interests would communicate their requests for assistance to the government, and the latter would goad the former into new investment efforts. These councils would seek out and gather information (from private sector and elsewhere) on investment ideas, achieve coordination among different state agencies when needed, push for changes in legislation and regulation to eliminate unnecessary transaction costs or other impediments, generate subsidies and financial backing for new activities when needed, and credibly bundle these different elements of support along with appropriate conditionalities. They can be created both at the national and sub-national or sectoral levels. Preferably, the larger of these councils would have their staff of technocrats.

Mechanisms of transparency and accountability. Industrial policies need to be viewed by society at large as part of a growth strategy that is geared to expand opportunities for all, rather than as giveaways to already privileged sections of the economy. This is particularly important 
since pro-active policies of the type discussed in this paper can sometimes be partial to bigger firms and entrepreneurs (unlike microcredit programs, say, or support of small and medium-sized enterprises). Hence promotion activities need to be undertaken in a transparent and accountable manner. The operation of the deliberation/coordination councils should be published and the decisions reached announced. There should be full accounting of public resources spent in support of new activities.

\section{$\underline{\text { Ten design principles for industrial policy }}$}

For reasons explained earlier, it is impossible (and undesirable) to specify ex ante the policy outputs that the type of architecture discussed above will yield. All depends on the opportunities and constraints that will be identified through the deliberative process. One country may choose to develop a services cluster around the expansion of the national port. Another may decide to set up public venture capital funds targeted at biotech and computer software. A third may go for tax breaks to encourage downstream processing of forestry products. A fourth may find it is excessive red tape and bureaucratic regulations that inhibit entreprenurship in new activities. Nonetheless, it is possible to list some general "design principles" that can inform the formulation of the resulting industrial policies.

1. Incentives should be provided only to "new" activities. The main purpose of industrial policy is to diversify the economy and generate new areas of comparative advantage. It follows that incentives ought to focus on economic activities that are new to the domestic economy. "New" refers to both products that are new to the local economy and to new technologies for producing an existing product. Many countries provide tax incentives for new investments without sufficiently discriminating between investments that expand the range of 
capabilities of the home economy and those that do not. Note also that this focus differs substantially from the tendency that many incentive programs have to subsidize small and medium sized enterprises (SMEs). SME support policies are based on the criterion of size - not on whether the activity in question has the potential to spawn new areas of specialization. It is the latter that produces economic growth.

2. There should be clear benchmarks/criteria for success and failure. As I have already emphasized, industrial policy is a necessarily experimental process. It is the nature of entrepreneurship that not all investments in new activities will pay off. And not all promotion efforts will be successful. In Korea, Taiwan, and Chile, successes have more than paid for the mistakes. But in the absence of a clear idea of what constitutes success and observable criteria for monitoring it, failures can get entrenched. Recipients of subsidies can game public agencies and continue to receive support despite poor outcomes. Bureaucrats administering incentives can claim success and keep their programs running. Ideally, the criteria for success should depend on productivity — both its rate of increase and its absolute level—and not on employment or output. While productivity can be notoriously difficult to measure, project audits by business and technical consultants can provide useful indications. So can benchmarking, using the experience of similar industries in neighboring countries. Performance in international markets (i.e., export levels) is also a good indicator, as it provides a quick-and-dirty way of gauging how the industry is doing relative to world-class competitors.

3. There must be a built-in sunset clause. One way to ensure that resources (both financial and human) do not remain tied up for a long time in activities that are not paying off is to phase out support by default. Hence, every publicly supported project needs to have not only 
a clear statement ex ante of what constitutes success and failure, but also an automatic sunset clause for withdrawing support after an appropriate amount of time has elapsed.

4. Public support must target activities, not sectors. It is common for investment promotion agencies to specify their priorities in terms of sectors or industries-e.g., tourism, call centers, or biotech. This leads to the misdirection of industrial promotion efforts. The targets of public support should be viewed not as sectors but as activities. This facilitates structuring the support as a corrective to specific market failures instead of generic support for this or that sector. Rather than providing investment incentives, say, for tourism or call centers, government programs should subsidize bilingual training, feasibility reports for nontraditional agriculture, infrastructure investment, adaptation of foreign technology to local conditions, risk and venture capital, and so on. Cross-cutting programs such as these have the advantage that they span several sectors at once and are targeted at market failures directly.

5. Activities that are subsidized must have the clear potential of providing spillovers and demonstration effects. There is no reason to provide public support to an activity unless that activity has the potential to crowd in other, complementary investments or generate informational or technological spillovers. Public support must be contingent on an analysis of this sort. Moreover, activities that are supported should be structured in such a way to maximize the spillovers to subsequent entrants and rivals.

6. The authority for carrying out industrial policies must be vested in agencies with demonstrated competence. It is common to complain about incompetence and corruption in government bureaucracies. But bureaucratic competence varies greatly among different agencies within the same country, and most countries have some pockets of bureaucratic competence. It is preferable to lodge promotion activities in such agencies instead of creating new agencies from 
scratch or using existing ones with poor track records. This will have an implication about the tools of industrial policy that can be used. If the development bank is in good shape but tax administration is a mess, promotion may need to be done through directed credit rather than tax incentives. Note how this may conflict with the requirement that policy tools be targeted as closely as possible to the source of a market failure. The location of competence may predetermine the tools used. But this is a necessary compromise: when administrative and human resources are scare, it is better to employ second-best instrument effectively than to use first-best instruments badly.

7. The implementing agencies must be monitored closely by a principal with a clear stake in the outcomes and who has political authority at the highest level. As we have seen, effective industrial policy requires a certain degree of autonomy for the bureaucratic agencies implementing it. But autonomy does not and should not mean lack of accountability. Close monitoring (and coordination) of the promotion activities by a cabinet-level politician, a "principal" who has internalized the agenda of economic restructuring and shoulders the main responsibility for it, is essential. Such monitoring guards not only against self-interested behavior on the part of the agencies, but also helps protect the agencies from capture by private interests. As suggested above, this principal could be a cabinet-level minister, a vice-president, or even the president (or prime minister) himself.

$\underline{\text { 8. The agencies carrying out promotion must maintain channels of communication with }}$ the private sector. Autonomy and insulation do not mean that bureaucrats must maintain arms' length relationships with entrepreneurs and investors. In fact, ongoing contacts and communication are important so as to allow public officials to have a good information base on business realities, without which sound decisionmaking would be impossible. 
9. Optimally, mistakes that result in "picking the losers" will occur. Public strategies of the sort advocated here are often derided because they may lead to picking the losers rather than the winners. It is important of course to build safeguards against this, as outlined above. But an optimal strategy of discovering the productive potential of a country will necessarily entail some mistakes of this type. Some promoted activities will fail. The objective should be not to minimize the chances that mistakes will occur, which would result in no self-discovery at all, but to minimize the costs of the mistakes when they do occur. If governments make no mistakes, it only means that they are not trying hard enough.

10. Promotion activities need to have the capacity to renew themselves, so that the cycle of discovery becomes an ongoing one. Just as there is no single blueprint for undertaking promotion, the needs and circumstances of productive discovery are likely to change over time. This requires that the agencies carrying out these policies have the capacity to reinvent and refashion themselves. Over time, some of the key tasks of industrial policy will have to be phased out while new ones are taken on.

\section{An illustrative range of incentive programs}

As I have argued, industrial policy should not be thought of as a generic range of incentive programs. It is instead a process designed to elicit areas where policy actions are most likely to make a difference. The output of such a process - the type of policies and approaches used — will depend critically on a county's own circumstances. Nonetheless, it may be useful to discuss briefly a number of illustrative programs in order to provide a more concrete sense of what industrial policies will entail. 
1. Subsidizing costs of "self-discovery". As I discussed above, uncertainty about what new products can be profitably produced constitutes a key obstacle to economic restructuring. The resolution of this uncertainty typically requires some upfront investments, as well as productive tinkering to get imported technologies to work well under local conditions. Since both of these areas are rife with externalities (successes can be easily emulated), the economic case for subsidizing them is strong. Therefore, governments will generally need a facility to defray the costs of the early stages of the cost discovery process. The manner in which this would be done can be envisaged as a "contest" whereby private-sector entrepreneurs would bid for public resources by bringing forth pre-investment proposals. The criteria for financing such studies would be that (i) they relate to substantially new activities; (ii) they have the potential to provide learning spillovers to others in the economy; and (iii) the private sector entities are willing to submit themselves to oversight and performance audits.

2. Developing mechanisms for higher risk finance. Going from the pre-investment phase of a project to the investment stage requires a more sizable expenditure of resources, which must be financed somehow. Commercial banks are typically not good at this: they intermediate deposits and must remain liquid for prudential reasons. Business development and selfdiscovery require longer term and riskier forms of financial intermediation. Other forms of risk finance, such as corporate debt markets, equity markets, or private venture capital funds, are also typically conspicuous by their absence. Hence governments will need alternative sources of finance. This may come in several different forms, depending on the available fiscal and bureaucratic resources. Some examples are: development banks, publicly funded (but professionally managed) venture funds, public guarantees for longer term commercial bank 
lending, or special vehicles that direct a share of public pension fund assets to a portfolio of higher risk investments.

3. Internalizing coordination externalities. Coordination externalities are highly specific to each activity and are essentially impossible to make concrete ex ante. The needs of tourism are very different than the needs of call centers. What this means is that governments need to have the capacity to identify these coordination failures and attempt to resolve them. The coordination and deliberation councils discussed above are one mechanism for instituting and developing such a capacity. But it is clear that these efforts need to be undertaken at multiple levels - both at the national level as well as the regional and sectoral levels. In all this, chambers of commerce and industry and farmer and labor associations can play a useful constructive role. As dicussed above, the government's relationships with these private-sector entities need to be socially legitimized through mechanisms of accountability and transparency. Proposals need to be made public, formally analyzed and evaluated by technocrats, and their fiscal impact costed out. The goal is to identify coordination opportunities while constraining inconvenient rentseeking behavior.

4. Public R\&D. Technology cannot be acquired from advanced countries in an off-theshelf manner. Whether it is table grapes in Chile or information technology in Taiwan, many new industries have required publicly funded R\&D efforts to identify, adapt, and transfer technology from abroad. The trick is to ensure that these efforts are well integrated with private sector activities and are targeted to their needs. Programs that work best are likely to be those that are responsive to private sector demands.

5. Subsidizing general technical training. New activities will eventually encounter a shortage of adequately trained personnel, even if this is not a binding constraint at the outset. 
Innovating firms will fear that labor turnover will reduce the returns to on-the-job training and will thus under-provide training. This will inevitably delay the process of self-discovery. So there is a strong case to be made for subsidizing training for vocational, technical and language skills. In general, public training facilities have a lousy reputation in developing countries, as they seem rarely targeted on the real needs of the private sector. Therefore, it may be preferable to offer subsidies or matching grants to private firms or institutes to co-finance their training efforts.

6. Taking advantage of nationals abroad. Many if not most developing countries have sizable numbers of migrant workers in the advanced countries. These workers tend to be among the most entrepreneurial in society, and often have higher skills than the workers at home (see Kapur and McHale forthcoming). Most governments look at these expatriate workers almost exclusively as a source of remittance income. But given their entpreneurialism, skills, and exposure to business in the developed world, as well as the desire of many of them to return home (under the right set of circumstances), they may well be far more valuable as a source of self-discovery at home. Governments can actively court them, encourage their return, and use them to spawn new domestic economic activities. If even a fraction of the tax incentives used to attract foreign investment is targeted at nationals abroad, the benefits could well be sizable.

\section{The exaggerated rumors of industrial policy's death}

An agenda of the sort laid out above may seem overly ambitious and too big a departure from today's accepted policy practice. After all, industrial policies are supposed to have been confined to the trashbin of history in modern and modernizing economies, along with other outmoded policies like central planning and trade protection. The reality is that industrial policies have run rampant during the last two decades - and nowhere more so than in those 
economies that have steadfastly adopted the agenda of orthodox reform. If this fact has escaped attention, it is only because the preferential policies in question have privileged exports and foreign investment - the two fetishes of the Washington Consensus era - and because their advocates have called them strategies of "outward orientation" and other similar sounding names instead of industrial policies. Anytime a government consciously favors some economic activities over others, it is conducting industrial policy. And by this standard, the recent past has seen more than its share of industrial policies.

While exports have been supported in a number of different ways, export processing zones (EPZs) are the most visible form of discrimination in their favor. There are close to 1000 EPZs around the world, and it is rare to find a country without one. Firms that locate in EPZs get favored treatment in a number of ways: they are allowed unlimited duty-free access on all their imports (provided they export their output); they receive tax holidays on corporate, property, and income taxes; they are generally sheltered from bureacratic regulations that other firms have to contend with; they are provided with superior infrastructure and communication services; they are often exempt from labor legislation that applies to other firms (Madani 1998).

Incentives offered to foreign direct investment are, if anything, more common. Practically all countries in the world have some government agency charged with attracting foreign investment and a program of tax holidays and other subsidies directed at foreign firms. In addition to these tax subsidies, foreign investors are offered one-stop shopping services, receive help in navigating through domestic regulatory requirements, sometimes receive trade protection in return for their investment, and often receive privileged legal status. For example, unlike domestic firms, foreign investors frequently have the option of submitting domestic legal disputes to international arbitration. Developing countries actively compete with each other to 
provide generous incentives to attract foreign firms, even though such incentives tend to play at best a marginal role in the location decisions of multinational firms.

The driving force behind the incentives in favor of exports and foreign investment has been the belief that these economic activities are particularly prone to positive externalities and spillovers. Exports and foreign direct investment are supposed to generate technological and learning spillovers for other activities. Hence, despite the decisive turn to markets during the last two decades, the dominant view among policy makers - revealed at least through their actionshas been that particular externalities remain rampant and need to be corrected through the deployment of generous subsidies. What stands out with this brand of industrial policy is the strong presumption that the important externalities reside in exports and direct foreign investment.

Economic research provides little support for this presumption. It has been known for a while that exporting firms tend to be more productive and technologically more dynamic than firms that sell mainly to the home market. We now know that the reason has to do, as a general rule, not with any benefits that accrue from the activity of exporting per se, but simply with selection effects: It is better firms (in all respects) that are able to or choose to export (see Tybout 2000 for a survey). Consequently, subsidizing exporting can do very little to enhance overall productive or technological capacity. Similarly, careful studies have been able to find very little systematic evidence of technological and other externalities from foreign direct investment, some even finding negative spillovers (see Hanson 2001 for a discussion of the issues). In these circumstances, subsidizing foreign investors is a particularly silly policy, as it serves to transfer income from poor-country taxpayers to the pockets of shareholders in rich countries, with no compensating benefit. 
Export processing zones and incentives for direct foreign investment are the most noticeable elements of industrial policy in developing countries, but they are not the only ones. Most countries have continued to maintain industrial policies of different types, some of which are the vestiges of import-substitution policies of the past and others are ad hoc responses to perceived shortcomings of existing policy setups. This is not adequately appreciated so I present in Table 2 an illustrative list of credit and tax incentives for domestic investment and production in a range of developing countries. The table is based on Melo (2001), which was confined to countries in South America, and expands Melo's compilation to countries in other parts of the world using national and international sources. As the table shows, credit facilities and tax incentives for favored sectors have been extremely widespread, in Latin America no less than in Asia and Africa. In Latin America, the incentives tend to be focused on tourism, mining, forestry, and agribusiness. Elsewhere, selected manufacturing and service industries also tend to get promoted.

The lesson from this survey of current practice is that industrial policy has far from disappeared. In most countries, the challenge is not to reinstitute industrial policy, but to redeploy the machinery that is already in place in a more productive manner. As we have just seen, much of today's industrial policy takes a presumptive stand on where the externalities are — exports and direct foreign investment—and is formulated in sectoral terms. The institutional architecture is rarely adequate to engage in the kind of discovery that I have advocated here. The overarching vision that informs their design is hardly ever articulated. Consequently, what is needed is not more industrial policy, but better industrial policy. Indeed, it would not be surprising if in many countries industrial policies could be rendered more 
effective by actually reducing their scope (and targeting them better). ${ }^{7}$

\section{$\underline{\text { V. Is Industrial Policy Still Feasible? }}$}

Developing countries operate today in a global policy environment that is much different than the one two or three decades ago. In particular, there has been a tendency to discipline national economic policies through multilateral, regional, or bilateral agreements. These disciplines impose restrictions on the ability of developing countries to conduct certain types of industrial poicies. I shall review these restrictions here. While it is true developing countries have a somewhat narrower room for policy autonomy today, it is easy to exaggerate the significance of the restrictions. There remains much scope for coherent industrial policy of the type I have outlined above, especially if countries do not give up policy autonomy voluntarily by signing up for bilateral agreements with the U.S. or for restrictive international codes. Few of the illustrative programs described in section III would come under international disciplines. What constrains sensible industrial policy today is largely the willingness to adopt it, not the ability to do so.

Restrictions on industrial policy come in different guises. ${ }^{8}$ I present a more detailed view of these in Table 3, and point to some general features here. Foremost in the hieararchy are the rules of the WTO, which are more far-reaching and intrusive than those under old GATT system. Previously, membership in the world trading system had few or no entry requirements for poor countries. The balance-of-payments and infant-industry exceptions were liberal enough to allow

\footnotetext{
${ }^{7}$ For example, Uruguay has a generous tax holiday program for new investments that does not discriminate between investments that are likely to generate the informational and coordination spillovers that I focused on above and those that are not. As a consequence, the program ends up financing projects such as the renovation of a hippodrome (which apparently was the largest project which has benefited from tax incentives so far).

${ }^{8}$ See also Lall (2004) for a discussion of existing constraints.
} 
countries to adopt any and all industrial policies. Under the WTO, there are several restrictions. Export subsidies are now WTO-illegal (for all but least-developed countries), as are domestic content requirements and other performance requirements on enterprises that are linked to trade, quantitative restrictions on imports, and patent laws that fall short of international standards. All of these had been part of the arsenal of industrial policies utilized by South Korea and Taiwan during the 1960s and 1970s. Moreover, countries that are not yet members of the WTO are often hit with more restrictive demands as part of their accession negotiations.

Regional or bilateral agreements typically expand the range of disciplines beyond those that are found in the WTO. In particular, the U.S. has pushed for tighter restrictions in the areas of investment regulations, intellectual property protection, and capital account whenever it negotiates a free-trade agreement with a developing country (see illustrations in Table 3). On the financial side, a number of international codes and standards have clauses that can be interepreted as restricting the use of industrial policy (see Table 3). And IMF conditionality often goes beyond narrow monetary and fiscal matters to prescribe policies on trade and industrial policy (so-called structural conditionality). The pinnacle of IMF structural conditionality was reached during the Asian financial crisis. While the IMF's official line has veered away from structural conditionality since then, IMF programs typically still contain many detailed requirements on trade and industrial policies (see Table 3 for illustrations from Turkey and Ethiopia).

It is important to emphasize that not all international disciplines are necessarily harmful. For example, the principle of transparency that is enshrined in international trade agreements and in international financial codes and standards is fully consistent with the industrial-policy architecture recommended above, and hence is hard to find fault with. Moreover, when designed 
appropriately, regional trade agreements can be a useful vehicle for industrial policy programs. For example, both Morocco and Tunisia put in place ambitious industrial upgrading (mise a niveau) programs in conjunction with their free-trade agreements with the EU, and obtained EU and World Bank funds to pay for them. Mercosur had a special regime for the automotive sector that gave a big boost to auto and components industries in Argentina and Uruguay. Governments with a strategic sense of their economic priorities can generally put such international agreements to good use, and transform potential constraint into opportunity.

Among existing international disciplines, probably the most significant is the one that constrains the use of export subsidies. The WTO's Agreement on Subsidies essentially renders illegal all Free Trade Zones of the type discussed previously (as well as other fiscal and credit incentives geared towards exports) for countries above the $\$ 1,000$ per-capita income level. How much of a real loss this is is not all that clear. As I discussed in the previous section, at present existing policies in many countries are probably too biased towards exporting as it is. There is nothing in the empirical literature to suggest that exports generate the kind of positive externalities that would justify their subsidization as a general rule. On the other hand, conditioning subsidies on exports has the valuable feature that it ensures the incentives are reaped by winners (i.e., those that are able to compete in international markets) rather than the losers. As such, export subsidies are a nice example of performance-based incentive policies (which makes them consistent with the design principles enunciated above). The success in East Asia with export subsidies has much to do with this carrot-and-stick feature: you get the subsidy, but only so long as you perform in world markets. On balance, therefore, the Agreement on Subsidies must be judged to have made a significant dent in the ability of developing countries to 
employ intelligently-designed industrial policies. ${ }^{9}$

A second area where international rules may have some bite is in intellectual property. As Richard Nelson (2003) has stressed, the ability to copy technologies developed in advanced countries has been historically one of the most important elements determining the ability of lagging nations to catch up. The WTO's TRIPS Agreeement and its more restrictive versions in bilateral/regional trade agreements make it virtually impossible to employ a strategy of reverse engineering and copying. The developmental costs of TRIPS has so far received attention mainly in regard to public health and access to essential medecines. Its adverse effects on technological capacity has yet to receive commensurate attention.

In light of this, it is encouraging that discussions of the multilateral trade regime are increasingly paying attention (or at least lip service) to the question of "policy space" for developing countries (see Hoekman 2004). There is growing recognition that the pendulum between policy autonomy and international rules may have swung too far in the direction of the latter in recent trade rounds. The attempt in the Doha Round to extend multilateral disciplines to national competition and investment policies has gone nowhere. And many consider the "single undertaking" model of trade negotiations adopted since the Uruguay Round and under which all nations, regardless of their levels of development and needs, sign on to the same text, to be all but dead. This is all good news from the perspective developed in this paper. Developing nations should push hard for "policy space" in future trade negotiations. In the past they compromised on that in return for greater market access in rich country markets. This has turned out to be a bad bargain. The purpose of international rules should be not to impose common

\footnotetext{
${ }^{9}$ Note that a prohibition on export subsidies cannot be justified using the traditional beggar-thy-neighbor arguments. Unlike, say, the use of import tariffs by a large country, the use of export subsidies produces a net benefit to the rest of the world since it lowers the world market price of the subsidized commodity and improves the external terms of trade of the rest of the world.
} 
rules on countries with different regulatory systems, but to accept these differences and regulate the interface between them so as to reduce adverse spillovers (Rodrik 2001).

\section{$\underline{\text { VI. Concluding Remarks }}$}

Markets can malfunction both when governments interfere too much and when they interfere too little. Development policies of the last two decades have been obsessed with the first category of policy mistakes - governments' errors of commission. Hence the efforts to reduce or eliminate regulations, trade restrictions, financial repression, and public ownership. Governments' errors of omission—needed interventions that were not supplied—were deemphasized, in part as a reaction to the strong emphasis placed on them by earlier policies of import substitution. Recently governments around the world have begun to seek a more balanced strategy, as liberalization and privatization have failed to deliver the expected performance. I have argued in this paper that properly formulated industrial policies have an important role to play in such strategies.

There is no shortage of arguments against industrial policy. A less than comprehensive list of such arguments would include the following.

- Governments cannot pick winners.

- Developing countries lack the competent buraucracies to render it effective.

- Industrial interventions are prone to political capture and corruption.

- There is little evidence that industrial policies work.

- What is needed is not industrial policy, but across-the-board support for R\&D and intellectual protection. 
- And in any case international rules no longer leave scope for industrial policy interventions.

There is more than a grain of truth in each of these claims. Yet, as we have seen, there are also good counter-arguments in each case.

- Yes, the government cannot pick winners, but effective industrial policy is predicated less on the ability to pick winners than on the ability to cut losses short once mistakes have been made. In fact, making mistakes ("picking wrong industries") is part and parcel of good industrial policy when cost discovery is at issue.

- Competent bureaucracies are a scarce resource in most developing countries, but most countries do have (or can build) pockets of bureaucratic competence. In any case, it is not clear what the counterfactual is. The standard market-oriented package hardly economizes on bureaucratic competence. As we have discovered during the last decade, and the expansion of the Washington Consensus agenda into governance and institutional areas indicate, running a market economy puts a significant premium on regulatory capacity. Industrial policy is no different.

- Industrial policies can be captured by the interests whose behavior they aim to alter. But once again, this is little different from any other area of policy. In many countries, privatization has turned out to be a boon for insiders or government cronies.

- It is not true that there is a shortage of evidence on the benefits of industrial policy. To the contrary, as I have illustrated above with reference to Latin America, it is difficult to come up with real winners in the developing world that are not a product of industrial policies of some sort. 
- Supply-side innovation policies may have a role, but what constrains productive restructuring is a more fundamental feature of low-income environments: entrepreneurship in new activities has high social returns but low private returns.

- There is plenty of scope for industrial policies in the present international economic environment. In fact, contrary to general belief, the last two decades have seen a tremendous amount of industrial policy.

I have taken the view in this paper that industrial policy is a process of economic selfdiscovery in the broader sense. The right image to carry in one's head is not of omniscient planners who can intervene with the first-best Pigovian subsidies to internalize any and all externalities, but of an interactive process of strategic cooperation between the private and public sectors which, on the one hand, serves to elicit information on business opportunities and constraints and, on the other hand, generates policy initiatives in response.

It is impossible to specify the results of such a process ex ante: the point is to discover where action is needed and what type of action can bring forth the greatest response. It is pointless to obsess, as is common in many discussions of industrial policy, about policy instruments and modalities of interventions. What is much more important is to have a process in place which helps reveal areas of desirable interventions. Governments that understand this will be constantly on the lookout for ways in which they can facilitate structural change and collaboration with the private sector. As such, industrial policy is a state of mind more than anything else.

I close by making two points that relate the discussion here to the broader policy agenda that faces developing countries. The first point is that much of industrial policy, as discussed here, is concerned with the provision of public goods for the productive sector. Public labs and 
public R\&D, health and infrastructural facilities, sanitary and phytosanitary standards, infrastructure, vocational and technical training can all be viewed as public goods required for enhancing technological capabilities. From this perspective, industrial policy is just good economic policy of the type that traditional, orthodox approaches prescribe. Secondly, the capacity to provide these public goods effectively is an important part of the social capabilities needed to generate development. That in turn requires good institutions, with the key features that I have discussed above. Such institutional development is at the core of today's orthodox development agenda. ${ }^{10}$ In both senses, then, the agenda of industrial policy laid out in this paper not only does not greatly differ from today's broader, conventional agenda of development, it is part and parcel of it.

\footnotetext{
${ }^{10}$ Paradoxically, as Ocampo $(2004,28)$ has rightly emphasized, the "suboptimal development of institutions in the area of productive development has ... become a direct institutional deficiency affecting economic growth, which is generally ignored in the call to strengthen institutional development."
} 


\section{REFERENCES}

Agosin, Manuel, "Trade and Growth in Chile: Past Performance and Future Prospects," Department of Economics, University of Chile, June 1999.

Amsden, Alice H., Asia's Next Giant: South Korea and Late Industrialization, Oxford University Press, New York and Oxford, 1989.

Clapp, Roger Alex, "Creating Comparative Advantage: Forest Policy as Industrial Policy in Chile," Economic Geography, vol 71, no. 3, July 1995, 273-96.

De Ferranti, David, Guillermo E. Perry, Daniel Lederman, and William F. Maloney, From Natural Resources to the Knowledge Economy, World Bank, Washington, DC, 2002.

Evans, Peter, Embedded Autonomy: States and Industrial Transformation, Princeton, NJ, Princeton University Press, 1995.

Hanson, Gordon H., "Should Countries Promote Foreign Direct Investment?" G-24 Discussion Paper No. 9, 2001.

Hausmann, Ricardo and Dani Rodrik, "Economic Development as Self-Discovery," Journal of Development Economics, vol. 72, December 2003.

Hausmann, Ricardo, and Dani Rodrik, “Discovering El Salvador's Production Potential,” John F. Kennedy School of Government, Harvard University, August 2003. (2003b)

Hoekman, Bernard, "Operationalizing the Concept of Policy Space in the WTO: Beyond Special and Differential Treatment," World Bank, 2004.

Imbs, Jean, and Romain Wacziarg, "Stages of Diversification," American Economic Review, 93(1), March 2003, 63-86.

Jarvis, Lovell S. Changing Private and Public Roles in Technological Development: Lessons from the Chilean Fruit Sector, in Agricultural Technology: Policy Issues for the International Community, J.R. Anderson, ed. Wallingford: CAB International, 1994.

Kapur, Devesh, and McHale, John, Sharing the Spoils: International Human Capital Flows and Developing Countries, Center for Global Development, Washington, DC, forthcoming.

Klinger, Bailey, and Daniel Lederman, "Discovery and Development: An Empirical Exploration of 'New' Products," World Bank, August 2004.

Lall, Sanjaya, "Reinventing Industrial Strategy: The Role of Government Policy in Building Industrial Competitiveness," G-24 Discussion Paper No. 28, April 2004.

Madani, Dorsati, “A Review of the Role and Impact of Export Processing Zones," World Bank, 1998. 
Melo, Alberto, "Industrial policy in Latin America at the turn of the century," IADB, Research Department WP No 459, 2001.

Nelson, Richard R., "The Changing Institutional Requirements for Technological and Economic Catch Up,” Columbia University, June 2004.

Ocampo, José Antonio, "Structural Dynamics and Economic Growth in Developing Countries," September 2004.

Pritchett, Lant, "Does Learning to Add Up Add Up? The Returns to Schooling in Aggregate Data," Kennedy School of Government, Harvard University, 2004.

Rodriguez-Clare, Andres, "Clusters and Comparative Advantage: Implications for Industrial Policy," Inter-American Development Bank, June 2004.

Rodrik, Dani, "Taking Trade Policy Seriously: Export Subsidization as a Case Study in Policy Effectiveness," in A. Deardorff, J. Levinson, and R. Stern (eds.), New Directions in Trade Theory, Ann Arbor, University of Michigan Press, 1995.

Rodrik, Dani, "Coordination Failures and Government Policy: A Model with Applications to East Asia and Eastern Europe," Journal of International Economics 40(1-2), February 1996, 122.

Rodrik, Dani, "The Global Governance of Trade as if Development Really Mattered," UNDP, New York, 2001.

Sabel, Charles F., "Beyond Principal-Agent Governance: Experimentalist Organizations, Learning and Accountability," Columbia University, July 2004 (to appear in Ewald Engelen \& Monika Sie Dhian Ho (eds.), De Staat van de Democratie. Democratie voorbij de Staat. WRR Verkenning 3, Amsterdam, Amsterdam University Press).

Sabel, Charles F., "Theory of a Real Time Revolution,” Columbia University, July 2003 (forthcoming in Organizational Studies, Winter 2004).

Sabel, Charles F., and Sanjay Reddy, "Learning to Learn: Undoing the Gordian Knot of Development Today," Columbia University, n.d.

Tybout, James R., "Manufacturing Firms in Developing Countries: How Well Do They Do, and Why?" Journal of Economic Literature 38(1) (March 2000), pp. 11-44.

Wade, Robert, Governing the Market, Princeton University Press, Princeton, NJ, 1990. 


\begin{tabular}{|llr|}
\hline Table 1: & Top 5 export items (HS4) to the U.S. (in 2000) \\
\hline Country Item & Value (\$ mil) \\
Brazil & aircraft & 1,435 \\
& shoes & 1,069 \\
& non-crude petroleum & 689 \\
& steel & 485 \\
& chemical woodpulp & 465 \\
& & \\
Chile & copper & 457 \\
& grapes & 396 \\
& fish & 377 \\
& lumber & 144 \\
& wood & 142 \\
& \\
Mexico & motor vehicles & 15,771 \\
& crude oil & 11,977 \\
computers \& peripherals & 6,411 \\
ignition wiring sets & 5,576 \\
trucks & 4,853
\end{tabular}


Table 2. Illustrative list of industrial policies in support of production and investment

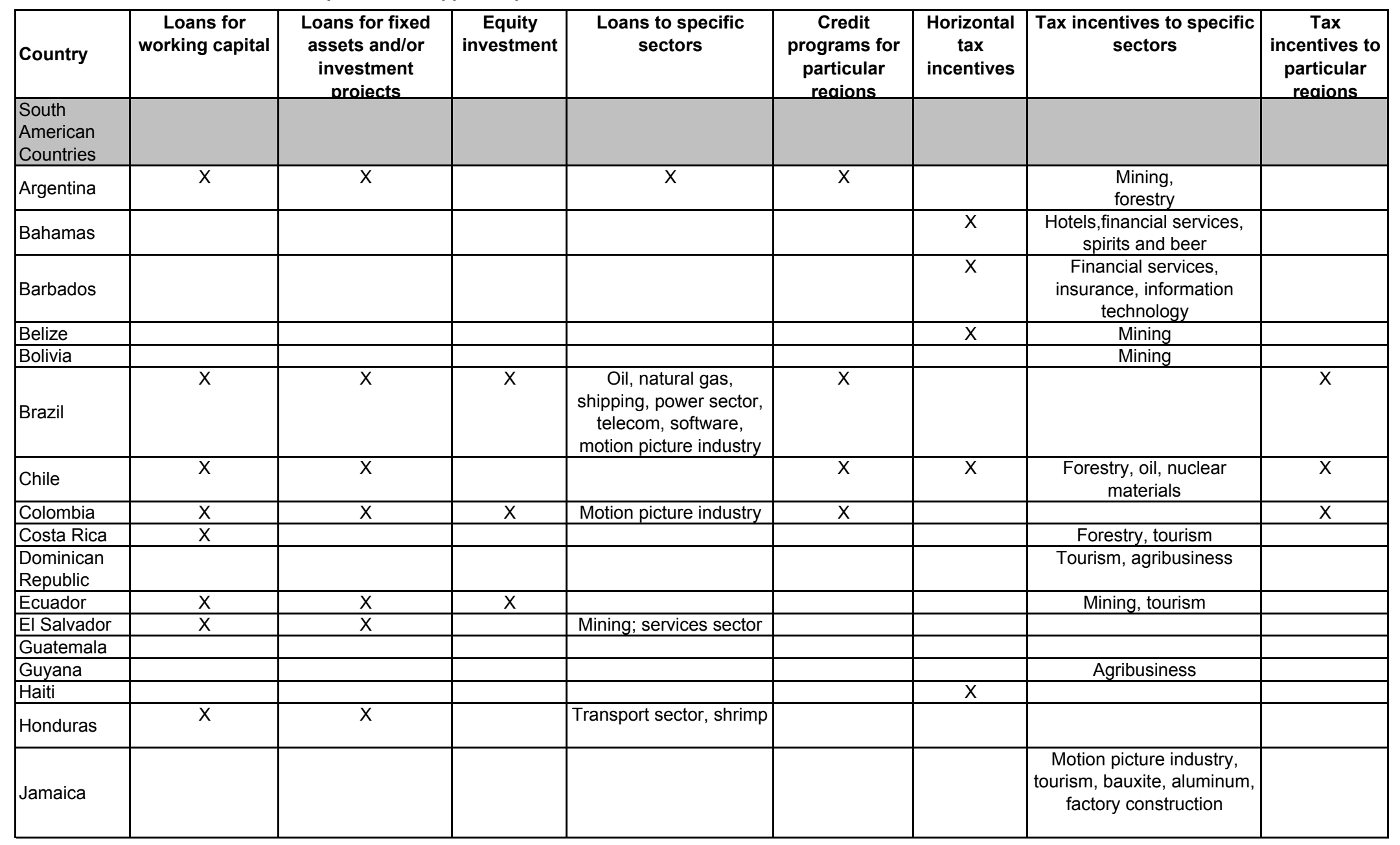


Table 2. Illustrative list of industrial policies in support of production and investment (cont.)

\begin{tabular}{|c|c|c|c|c|c|c|c|c|}
\hline Country & $\begin{array}{c}\text { Loans for } \\
\text { working capital }\end{array}$ & $\begin{array}{l}\text { Loans for fixed } \\
\text { assets and/or } \\
\text { investment } \\
\text { projects }\end{array}$ & $\begin{array}{c}\text { Equity } \\
\text { investment }\end{array}$ & $\begin{array}{l}\text { Loans to specific } \\
\text { sectors }\end{array}$ & $\begin{array}{l}\text { Credit } \\
\text { programs for } \\
\text { particular } \\
\text { reqions } \\
\end{array}$ & $\begin{array}{l}\text { Horizontal } \\
\operatorname{tax} \\
\text { incentives }\end{array}$ & $\begin{array}{c}\text { Tax incentives to specific } \\
\text { sectors }\end{array}$ & \begin{tabular}{|c|} 
Tax \\
incentives to \\
particular \\
reqions \\
\end{tabular} \\
\hline Mexico & $x$ & $\mathrm{X}$ & $x$ & Motion picture industry & & $\mathrm{x}$ & $\begin{array}{l}\text { Forestry, motion picture } \\
\text { industry, air and maritime } \\
\text { transportation, publishing } \\
\text { industry }\end{array}$ & \\
\hline \begin{tabular}{|l|} 
Nicaragua \\
\end{tabular} & $\mathrm{X}$ & $\mathrm{X}$ & & & & & Tourism & \\
\hline Panama & $\mathrm{X}$ & $\mathrm{X}$ & & & & & Tourism, forestry & \\
\hline Paraguay & $\mathrm{x}$ & $\mathrm{X}$ & & & & $\mathrm{X}$ & & $\mathrm{X}$ \\
\hline Peru & $\mathrm{X}$ & $\mathrm{X}$ & & & & & Tourism, mining, oil & $\mathrm{X}$ \\
\hline Surinam & & & & & & $\mathrm{x}$ & & \\
\hline $\begin{array}{l}\text { Trinidad \& } \\
\text { Tobago } \\
\end{array}$ & & & & & & $\mathrm{X}$ & Hotels, construction & \\
\hline Uruguay & $\mathrm{x}$ & $\bar{x}$ & & & & $\mathrm{x}$ & $\begin{array}{c}\text { Hydrocarbons, printing } \\
\text { shipping, forestry, military } \\
\text { industry, airlines, } \\
\text { newspapers, broadcasters } \\
\text { theaters, motion picture } \\
\text { industry }\end{array}$ & \\
\hline Venezuela & $\mathrm{x}$ & $x$ & & & & $\mathrm{x}$ & $\begin{array}{c}\text { Hydrocarbons and other } \\
\text { primary sectors }\end{array}$ & \\
\hline \multicolumn{9}{|l|}{$\begin{array}{l}\text { Other } \\
\text { countries }\end{array}$} \\
\hline India & $\mathrm{X}$ & $\bar{X}$ & $?$ & $\begin{array}{l}\text { Motion Picture Industry, } \\
\text { jute textiles, tea } \\
\text { plantations }\end{array}$ & $\mathrm{x}$ & $\mathrm{x}$ & $\begin{array}{l}\text { infrastructure facilities, } \\
\text { Power projects, new } \\
\text { industries in electronic } \\
\text { hardware/software } \\
\text { parks,airports, ports, inland } \\
\text { ports and waterways, and } \\
\text { industrial parks,for hotels, } \\
\text { cold-storage firms and } \\
\text { manufacturers of priority } \\
\text { items. }\end{array}$ & $\mathrm{x}$ \\
\hline
\end{tabular}


Table 2. Illustrative list of industrial policies in support of production and investment (cont.)

\begin{tabular}{|c|c|c|c|c|c|c|c|c|}
\hline Country & $\begin{array}{c}\text { Loans for } \\
\text { working capital }\end{array}$ & $\begin{array}{l}\text { Loans for fixed } \\
\text { assets and/or } \\
\text { investment } \\
\text { projects }\end{array}$ & \begin{tabular}{c|c|} 
Equity \\
investment
\end{tabular} & $\begin{array}{l}\text { Loans to specific } \\
\text { sectors }\end{array}$ & $\begin{array}{l}\text { Credit } \\
\text { programs for } \\
\text { particular } \\
\text { regions }\end{array}$ & $\begin{array}{l}\text { Horizontal } \\
\text { tax } \\
\text { incentives }\end{array}$ & $\begin{array}{c}\text { Tax incentives to specific } \\
\text { sectors }\end{array}$ & $\begin{array}{c}\text { Tax } \\
\text { incentives to } \\
\text { particular } \\
\text { reqions }\end{array}$ \\
\hline China & $\mathrm{X}$ & $X$ & $?$ & Software, & $x$ & $?$ & \begin{tabular}{|l|} 
Hight Tech. IC \\
manufacturers and software \\
development enterprises \\
that source production \\
equipment made \\
domestically in China.
\end{tabular} & $x$ \\
\hline Malaysia & $\bar{X}$ & $\bar{X}$ & $?$ & $\begin{array}{l}\text { Shipping industry, } \\
\text { Shipyard Industry and } \\
\text { maritime Related } \\
\text { Activities }\end{array}$ & $\bar{x}$ & $?$ & $\begin{array}{l}\text { Manufacturing } \\
\text { Sector,Technology } \\
\text { Industries, Agricultural } \\
\text { Sector, Tourism Industry, } \\
\text { Research and } \\
\text { Development, Software, } \\
\text { Computers and ICT }\end{array}$ & $\bar{X}$ \\
\hline Thailand & $\bar{X}$ & $\bar{X}$ & $\bar{X}$ & $?$ & $?$ & $?$ & $\begin{array}{l}\text { agriculture and agricultural } \\
\text { products, direct involvement } \\
\text { in technological and human } \\
\text { resource development, } \\
\text { public utilities and } \\
\text { infrastructure, } \\
\text { environmental protection } \\
\text { and conservation, and } \\
\text { targeted industries. }\end{array}$ & $\mathrm{X}$ \\
\hline Nigeria & $\mathrm{X}$ & $\mathrm{X}$ & $?$ & Agriculture & $\mathrm{X}$ & $?$ & $\begin{array}{l}\text { Agriculture, Oil and Gas } \\
\text { sectors, Minerals such as } \\
\text { Barytes, Gypsum, Kaolin } \\
\text { and Marble, Energy Sector }\end{array}$ & $x$ \\
\hline
\end{tabular}


Table 2. Illustrative list of industrial policies in support of production and investment (cont.)

\begin{tabular}{|c|c|c|c|c|c|c|c|c|}
\hline Country & $\begin{array}{c}\text { Loans for } \\
\text { working capital }\end{array}$ & $\begin{array}{c}\text { Loans for fixed } \\
\text { assets and/or } \\
\text { investment } \\
\text { projects }\end{array}$ & $\begin{array}{c}\text { Equity } \\
\text { investment }\end{array}$ & $\begin{array}{l}\text { Loans to specific } \\
\text { sectors }\end{array}$ & $\begin{array}{l}\text { Credit } \\
\text { programs for } \\
\text { particular } \\
\text { regions }\end{array}$ & $\begin{array}{l}\text { Horizontal } \\
\text { tax } \\
\text { incentives }\end{array}$ & $\begin{array}{c}\text { Tax incentives to specific } \\
\text { sectors }\end{array}$ & \begin{tabular}{|c|} 
Tax \\
incentives to \\
particular \\
reqions
\end{tabular} \\
\hline Ghana & $\mathrm{X}$ & $\mathrm{X}$ & $?$ & \begin{tabular}{|l|} 
manufacturing and \\
processing industries, \\
including agro-industrial, \\
fishing and agricultural \\
sectors - food \\
production, livestock \\
breeding, poultry farming \\
and processing of \\
agricultural produce
\end{tabular} & $?$ & $?$ & $\begin{array}{c}\text { Non-Traditional Export, } \\
\text { Hotels, Real Estate, Rural } \\
\text { Banks, Agriculture and agro- } \\
\text { industry, Waste Processing, } \\
\text { Free Zones } \\
\text { Enterprise/Development }\end{array}$ & $x$ \\
\hline Uganda & $\mathrm{X}$ & $\mathrm{X}$ & $?$ & \begin{tabular}{|l|} 
Agriculture, Forestry, \\
Animal Husbandry \\
including pisciculture, \\
Agro-industries including \\
manufacturing and \\
distribution of agricultural \\
inputs
\end{tabular} & $?$ & $?$ & $\begin{array}{l}\text { Plants, machinery and } \\
\text { construction materials }\end{array}$ & $x$ \\
\hline
\end{tabular}


Table 2. Illustrative list of industrial policies in support of production and investment (cont.)

\begin{tabular}{|c|c|c|c|c|c|c|c|c|}
\hline India & $\begin{array}{l}\text { http://www.idbi.co } \\
\mathrm{m} /\end{array}$ & http://www.idbi.com/ & - & \begin{tabular}{|l|} 
http://www.idbi.com/, \\
http://www.finance.india \\
mart.com/exports_import \\
s/incentives/index.html
\end{tabular} & $\begin{array}{l}\text { http://www.finan } \\
\text { ce.indiamart.co } \\
\text { m/exports_impo } \\
\text { rts/incentives/in } \\
\text { dex.html } \\
\end{array}$ & EIU & $\begin{array}{l}\text { http://www.finance.indiamart } \\
\text {.com/exports_imports/incent } \\
\text { ives/general_tax_incentives. } \\
\text { html and ElU }\end{array}$ & $\begin{array}{l}\text { http://www.tec } \\
\text { hno- } \\
\text { preneur.net/ti } \\
\text { meis/haryana/i } \\
\text { ncentive.html }\end{array}$ \\
\hline China & $\begin{array}{l}\text { EIU (general } \\
\text { Incentives) }\end{array}$ & $\begin{array}{l}\text { EIU (general } \\
\text { Incentives) }\end{array}$ & - & - & \begin{tabular}{|l|} 
http://english1.p \\
eopledaily.com. \\
cn/english/2000 \\
05/18/eng20000 \\
518_41146.html
\end{tabular} & - & \begin{tabular}{|l|} 
http://www.ey.com/GLOBAL \\
/content.nsf/China_E/Tax__- \\
-Tax_Insight_- \\
_2003_July_31
\end{tabular} & $\begin{array}{l}\text { http://www.hsb } \\
\text { c.com.hk/hk/c } \\
\text { orp/aoc/businf. } \\
\text { htm }\end{array}$ \\
\hline Malaysia & $\begin{array}{l}\text { http://www.smide } \\
\text { c.gov.my/detailpa } \\
\text { ge.jsp?section=fi } \\
\text { nancialassistanc } \\
\text { e\&subsection=lo } \\
\text { an\&detail=bankin } \\
\text { dustri3\&level=4 }\end{array}$ & $\begin{array}{l}\text { http://www.smidec.g } \\
\text { ov.my/detailpage.jsp } \\
\text { ?section=financialas } \\
\text { sistance\&subsection } \\
\text { =loan\&detail=bankin } \\
\text { dustri3\&level=4 }\end{array}$ & - & $\begin{array}{l}\text { http://www.smidec.gov.m } \\
\text { y/detailpage.jsp?section } \\
\text { =financialassistance\&su } \\
\text { bsection=loan\&detail=ba } \\
\text { nkindustri3\&level=4 }\end{array}$ & EIU & - & $\begin{array}{l}\text { http://e- } \\
\text { directory.com.my/web/sw- } \\
\text { investorinfo-incentive.htm }\end{array}$ & $\begin{array}{l}\text { http://www.mid } \\
\text { a.gov.my }\end{array}$ \\
\hline Thailand & $\begin{array}{l}\text { http://www.ifct.co. } \\
\text { th/database/index } \\
\text {.asp?l=eng and }\end{array}$ & $\begin{array}{l}\text { Industrail Finance } \\
\text { Corporation of } \\
\text { Thailand }\end{array}$ & $\begin{array}{l}\text { http://www.ifc } \\
\text { t.co.th/datab } \\
\text { ase/index.as } \\
\text { p?mid=7\&sid } \\
=15 \& \text { cid }=54\end{array}$ & & & - & $\begin{array}{l}\text { http://www.deltha.cec.eu.int/ } \\
\text { bic/doing_business_thailand } \\
\text { /incentive_investment_prom } \\
\text { otion_act.htm }\end{array}$ & $\begin{array}{l}\text { http://www.delt } \\
\text { ha.cec.eu.int/b } \\
\text { ic/doing_busin } \\
\text { ess_thailand/in } \\
\text { centive_invest } \\
\text { ment_promotio } \\
\text { n_act.htm }\end{array}$ \\
\hline Nigeria & \begin{tabular}{|l|} 
http://www.nigeria \\
businessinfo.com \\
/ifcfinance- \\
nigeria2002.htm
\end{tabular} & $\begin{array}{l}\text { http://www.nigeriabu } \\
\text { sinessinfo.com/ifcfin } \\
\text { ance- } \\
\text { nigeria2002.htm }\end{array}$ & & $\begin{array}{l}\text { http://www.nipc- } \\
\text { nigeria.org/dfi.htm The } \\
\text { Nigerian Industrial } \\
\text { Development Bank } \\
\text { (NIDB) }\end{array}$ & EIU & - & \begin{tabular}{|l|} 
http://www.nigeria.gov.ng/bu \\
siness/incentives.htm
\end{tabular} & $\begin{array}{l}\text { http://www.nig } \\
\text { eria.gov.ng/bu } \\
\text { siness/incentiv } \\
\text { es.htm }\end{array}$ \\
\hline Ghana & $\begin{array}{r}\text { The National Inv } \\
\text { industrial develop } \\
\text { financial assistan } \\
\text { and process } \\
\text { including agro-in } \\
\text { we }\end{array}$ & $\begin{array}{l}\text { vestment Bank is an } \\
\text { oment bank providing } \\
\text { רce to manufacturing } \\
\text { sing industries, } \\
\text { hdustrial projects.(no } \\
\text { b site) }\end{array}$ & - & $\begin{array}{l}\text { but don know which } \\
\text { specific sectors } \\
\text { http://www.ghana- } \\
\text { embassy.org/financial_in } \\
\text { titutions.htm }\end{array}$ & - & - & $\begin{array}{l}\text { http://www.gipc.org.gh/IPA_I } \\
\text { nformation.asp?hdnGroupID } \\
=3 \& \text { hdnLevellD=3 }\end{array}$ & $\begin{array}{l}\text { http://www.gip } \\
\text { c.org.gh/IPA_I } \\
\text { nformation.asp } \\
\text { ?hdnGroupID= } \\
\text { 3\&hdnLevellD } \\
=3\end{array}$ \\
\hline Uganda & \begin{tabular}{|l|} 
http://www.bou.or \\
.ug/DevFIN.htm
\end{tabular} & $\begin{array}{l}\text { http://www.bou.or.ug } \\
\text { /DevFIN.htm }\end{array}$ & - & $\begin{array}{l}\text { http://www.bou.or.ug/De } \\
\text { vFIN.htm }\end{array}$ & - & - & $\begin{array}{l}\text { http://www.unctad.org/en/do } \\
\text { cs//iteipcmisc3_en.pdf }\end{array}$ & $\begin{array}{l}\text { http://www.uga } \\
\text { ndainvest.com } \\
\text { /incentives.htm }\end{array}$ \\
\hline
\end{tabular}


Table 3: Restrictions imposed by international agreements on the ability of countries to undertake industrial policies.

\begin{tabular}{|c|c|c|}
\hline Restriction & How the restriction is defined & Under what condition it applies \\
\hline \multicolumn{3}{|l|}{ WTO } \\
\hline Most Favored Nation & $\begin{array}{l}\text { A product made in one member country be treated no less favorably than } \\
\text { "like" good that originates in another country }\end{array}$ & $\begin{array}{l}\text { It applies unconditionally. Although exceptions are made for the } \\
\text { formation of free trade areas or custom unions and for } \\
\text { preferential treatment of developing countries }\end{array}$ \\
\hline National Treatment & $\begin{array}{l}\text { Foreign gods, once they have satisfied whatever border measures are } \\
\text { applied, be treated no less favorably, in thermos of internal taxation than } \\
\text { like or directly competitive domestically produced good }\end{array}$ & $\begin{array}{l}\text { The obligation applies whether or not a specific tariff commitme } \\
\text { was made, and it cover taxes and other policies, which must be } \\
\text { applied in a non discriminatory fashion to like domestic and } \\
\text { foreign products }\end{array}$ \\
\hline Reciprocity & $\begin{array}{l}\text { Mutual or correspondent concessions of advantages or privileges in the } \\
\text { commercial relations between two countries }\end{array}$ & $\begin{array}{l}\text { The developed contracting parties do not expect reciprocity for } \\
\text { commitments made by them in trade negotiations to reduce or } \\
\text { remove tariffs an the barriers to the trade of less developed } \\
\text { contracting parties (yet, this condition is not legally binding) }\end{array}$ \\
\hline Safeguard Actions & $\begin{array}{l}\text { A WTO member may take a "safeguard" action (i.e., restrict imports of a } \\
\text { product temporarily) to protect a specific domestic industry from an } \\
\text { increase in imports of any product which is causing, or which is } \\
\text { threatening to cause, serious injury to the industry }\end{array}$ & $\begin{array}{l}\text { a) to attain no economic objectives (public health or national } \\
\text { security) b) to ensure fair competition ( antidumping measures, } \\
\text { etc) c) economic reasons (serious balance of payment deficits } \\
\text { desire of the government to support infant industries) }\end{array}$ \\
\hline Antidumping agreem & $\begin{array}{l}\text { Impose discipline son the use of antidumping by countries. Is one of the } \\
\text { main safeguard instruments used among developing countries }\end{array}$ & $\begin{array}{l}\text { Contains a number of provisions aimed at reducing the extent to } \\
\text { which antidumping can be used against developing countries } \\
\text { that are trying to develop their exports }\end{array}$ \\
\hline $\begin{array}{l}\text { Agreement on } \\
\text { Subsidies and } \\
\text { Countervailing } \\
\text { Measures (SCM) }\end{array}$ & $\begin{array}{l}\text { Prohibits exports subsidies by countries with incomes per capita above } \\
\text { U } \$ 1.000 \text { and lays out rules for the use of countervailing measures to offse } \\
\text { injury to domestic industries caused by foreign production subsidies }\end{array}$ & $\begin{array}{l}\text { Provision related to developing countries: If the subsidy is less } \\
\text { than } 2 \% \text { of the per unit value of the product exported, developin } \\
\text { countries are exempt form countervailing measures (whereas th } \\
\text { figure is } 1 \% \text { when a product from and industrial country is under } \\
\text { investigation }\end{array}$ \\
\hline $\begin{array}{l}\text { Agreement on trade } \\
\text { related Investment } \\
\text { Measures }\end{array}$ & $\begin{array}{l}\text { Prohibits the use of a number of investment performance-related } \\
\text { measures that have an effect on trade: local content and trade-balancing } \\
\text { requirements }\end{array}$ & $\begin{array}{l}\text { The agreement requires mandatory notification of all non- } \\
\text { conforming TRIMs and their elimination within two years for } \\
\text { developed countries, within five years for developing countries } \\
\text { and within seven years for least-developed countries. }\end{array}$ \\
\hline TRIPS Agreement & $\begin{array}{l}\text { The IP areas covered are patents and the protection of plant varieties; } \\
\text { copyrights and related rights, undisclosed information, trademarks, } \\
\text { geographical indications, industrial designs, and the layout of designs of } \\
\text { integrated circuits. Generally, IP gives creators exclusive rights over the } \\
\text { use of their creations for a fixed duration of time. In some cases however, } \\
\text { the IPR are valid indefinitely. }\end{array}$ & $\begin{array}{l}\text { The required strengthening of protection of intellectual property } \\
\text { rights (IPR) has implications for industrial policy. In the case of } \\
\text { domestic firms, it implies both a need to and greater incentives } \\
\text { innovate and compete dynamically, reverse engineering and } \\
\text { imitations has become less feasible. For foreign firms it means } \\
\text { that market access through a commercial presence may becom } \\
\text { more attractive as IPR protection improves TRIPS Article } 66.2 \\
\text { requires industrial countries to support technology transfer to } \\
\text { least developed countries. }\end{array}$ \\
\hline
\end{tabular}




\begin{tabular}{|c|c|c|}
\hline Restriction & How the restriction is defined & Under what condition it applies \\
\hline \multicolumn{3}{|c|}{ International Financial Codes and Standards } \\
\hline \multicolumn{3}{|c|}{ Basel Core Principles for Effective Banking Supervision } \\
\hline $\begin{array}{l}\text { Directed lending and } \\
\text { connected lending }\end{array}$ & $\begin{array}{l}\text { Bank supervisors must set prudential limits to restrict bank exposures to } \\
\text { single borrowers or groups of related borrowers; they must have in place } \\
\text { requirements that banks lend to related companies and individuals on an } \\
\text { arm's-length basis, that such extensions of credit are effectively monitore } \\
\text { and that other appropriate steps are taken to control or mitigate the risks. }\end{array}$ & $\begin{array}{l}\text { These principles are voluntary, but compliance with them is } \\
\text { frequently checked in the context of World Bank or IMF } \\
\text { programs. }\end{array}$ \\
\hline \multicolumn{3}{|c|}{ Code of Good Practices on Transparency in Monetary and Financial Policies } \\
\hline $\begin{array}{l}\text { Transparency of } \\
\text { financial practices in } \\
\text { support of } \\
\text { government policies }\end{array}$ & $\begin{array}{l}\text { Requires transparency in the conduct of Central Banking and financial } \\
\text { operations, inter alia, when those operations are undertaken in suppotr of } \\
\text { government economic policies. }\end{array}$ & $\begin{array}{l}\text { These principles are voluntary, but compliance with them is } \\
\text { frequently checked in the context of World Bank or IMF } \\
\text { programs. }\end{array}$ \\
\hline \multicolumn{3}{|c|}{ Code of Good Practices on Fiscal Transparency } \\
\hline $\begin{array}{l}\text { Nondiscrimination in } \\
\text { government } \\
\text { regulation }\end{array}$ & $\begin{array}{l}\text { Government involvement in the private sector (e.g., through regulation an } \\
\text { equity ownership) should be conducted in an open and public manner, an } \\
\text { on the basis of clear rules and procedures that are applied in a } \\
\text { nondiscriminatory way. }\end{array}$ & $\begin{array}{l}\text { बinhese principles are voluntary, but compliance with them is } \\
\text { direquently checked in the context of World Bank or IMF } \\
\text { programs. }\end{array}$ \\
\hline \multicolumn{3}{|c|}{\begin{tabular}{|l|l|} 
Regional trade agreements \\
NAFTA
\end{tabular}} \\
\hline Tariff Elimination & $\begin{array}{l}\text { Except as otherwise provided in this Agreement, no Party may increase } \\
\text { any existing customs duty, or adopt any customs duty, on an originating } \\
\text { good }\end{array}$ & $\begin{array}{l}\text { Each Party may adopt or maintain import measures to allocate in } \\
\text { quota imports, provided that such measures do not have trade } \\
\text { restrictive effects on imports additional to those caused by the } \\
\text { imposition of the tariff rate quota. }\end{array}$ \\
\hline $\begin{array}{l}\text { Restriction on } \\
\text { Drawback and Duty } \\
\text { Deferral Programs }\end{array}$ & $\begin{array}{l}\text { 1) No Party may refund the amount of customs duties paid, or waive or } \\
\text { reduce the amount of customs duties owed, on a good imported into its } \\
\text { territory.2) No Party may, on condition of export, refund, waive or reduce: } \\
\text { a) an antidumping or countervailing duty that is applied pursuant to a } \\
\text { Party's domestic law }\end{array}$ & $\begin{array}{l}\text { This Article does not apply to: a) a good entered under bond for } \\
\text { transportation and exportation to the territory of another Party; b } \\
\text { a good exported to the territory of another Party in the same } \\
\text { condition as when imported into the territory of the Party from } \\
\text { which the good was exported (processes such as testing, } \\
\text { cleaning, repacking or inspecting the good, or preserving it in its } \\
\text { same condition, shall not be considered to change a good's } \\
\text { condition).c) a refund of customs duties by a Party on a } \\
\text { particular good imported into its territory and subsequently } \\
\text { exported to the territory of another Party }\end{array}$ \\
\hline $\begin{array}{l}\text { Waiver of Customs } \\
\text { Duties }\end{array}$ & $\begin{array}{l}\text { No party may adopt any new waiver of customs duties, or expand with } \\
\text { respect to existing recipients or extend to any new recipient the applicatio } \\
\text { of an existing waiver of customs duties, where the waiver is conditioned, } \\
\text { explicitly or implicitly, on the fulfillment of a performance requirement. }\end{array}$ & $\begin{array}{l}\text { This Article shall not apply to measures subject to Article } 303 \\
\text { (Restriction on Drawbacks and Duty Deferral Programs) }\end{array}$ \\
\hline
\end{tabular}




\begin{tabular}{|c|c|c|}
\hline Restriction & How the restriction is defined & Under what condition it applies \\
\hline $\begin{array}{l}\text { Investment: } \\
\text { Performance } \\
\text { requirements }\end{array}$ & \begin{tabular}{|l|} 
No Party may impose or enforce any of the following requirements, to an \\
investment or an investor of a Party or of a non-Party in its territory: (a) to \\
export a given level or percentage of goods or services; (b) to achieve a \\
given level or percentage of domestic content; (c) to purchase, use or \\
accord a preference to goods produced or services provided in its territor, \\
or to purchase goods or services from persons in its territory; (d) to relate \\
in any way the volume or value of imports to the volume or value of expor \\
or to the amount of foreign exchange inflows associated with such \\
investment; (e) to restrict sales of goods or services in its territory that \\
such investment produces or provides by relating such sales in any way th \\
the volume or value of its exports or foreign exchange earnings; (f) to \\
transfer technology; or (g) to act as the exclusive supplier of the goods it \\
produces or services it provides to a specific region or world market.
\end{tabular} & $\begin{array}{l}\text { Provided that such measures are not applied in an arbitrary or } \\
\text { unjustifiable manner, or do not constitute a disguised restriction } \\
\text { on international trade or investment, the restriction does not } \\
\text { prevent any Party from adopting or maintaining measures, } \\
\text { including environmental measures: } \\
\text { (a) necessary to secure compliance with laws and regulations } \\
\text { that are not inconsistent with the provisions of this Agreement; } \\
\text { (b) necessary to protect human, animal or plant life or health; or } \\
\text { (c) necessary for the conservation of living or non-living } \\
\text { pexhaustible natural resources. }\end{array}$ \\
\hline $\begin{array}{l}\text { Import and Export } \\
\text { Restrictions }\end{array}$ & $\begin{array}{l}\text { Except as otherwise provided in this Agreement, no Party may adopt or } \\
\text { maintain any prohibition or restriction on the importation of any good of } \\
\text { another Party or on the exportation or sale for export of any good destine } \\
\text { for the territory of another Party, . }\end{array}$ & $\begin{array}{l}\text { Applies under all conditions except in accordance with Article XI } \\
\text { of the GATT, including its interpretative notes, and to this end } \\
\text { AArticle XI of the GATT and its interpretative notes, or any } \\
\text { equivalent provision of a successor agreement to which all } \\
\text { Parties are party, are incorporated into and made a part of this } \\
\text { Agreement }\end{array}$ \\
\hline \multicolumn{3}{|l|}{ EU } \\
\hline $\mid \begin{array}{l}\text { Freedom of } \\
\text { movement for goods }\end{array}$ & $\begin{array}{l}\text { It follows from the abolition, in intra-Community trade, of customs duties } \\
\text { and charges having equivalent effect in addition to quantitative restriction } \\
\text { in trade and measures having equivalent effect. In both cases, the } \\
\text { dismantling of barriers is based on the standstill concept, according to } \\
\text { which Member States are not authorized to restore such instruments } \\
\text { between themselves. }\end{array}$ & It applies unconditionally \\
\hline $\begin{array}{l}\text { Freedom of } \\
\text { movement for } \\
\text { services }\end{array}$ & $\begin{array}{l}\text { The concept of the freedom to perform services is closely linked to the } \\
\text { right of establishment. In both cases, the non-national or Community } \\
\text { business in question must be given national treatment i.e. the conditions } \\
\text { applied to them must not be different from those applied to nationals or } \\
\text { national businesses. }\end{array}$ & $\begin{array}{l}\text { Certain limits have been set by the Treaty, which excludes } \\
\text { services linked to the civil service and which stipulates that } \\
\text { restrictions on the freedom to perform services can be justified } \\
\text { on grounds of public policy, public security and public health. In } \\
\text { addition, certain sectors such as transport, banking and } \\
\text { insurance also have their own systems. These sectors have } \\
\text { usually been subject to substantial regulation in the Member } \\
\text { States and the application of the freedom of movement for } \\
\text { services could not easily be achieved simply through mutual } \\
\text { recognition of standards. }\end{array}$ \\
\hline
\end{tabular}




\begin{tabular}{|c|c|c|}
\hline Restriction & How the restriction is defined & Under what condition it applies \\
\hline $\begin{array}{l}\text { Freedom of } \\
\text { movement for capital }\end{array}$ & $\begin{array}{l}\text { In connection with the free movement of capital, the Treaty prohibits all } \\
\text { restrictions on capital movements (investments) and all restrictions on } \\
\text { payments (payment for goods or services). }\end{array}$ & $\begin{array}{l}\text { Member States are, however, authorized to take any measure } \\
\text { justified by the wish to prevent infringements of their own } \\
\text { legislation, specifically relating to fiscal provisions or prudential } \\
\text { supervision of financial institutions. Moreover, Member States } \\
\text { may lay down procedures for declaring capital movements for } \\
\text { administrative or statistical information purposes in addition to } \\
\text { measures associated with public policy or public security. } \\
\text { However, these measures and procedures must not be a means } \\
\text { of arbitrary discrimination or a disguised restriction on the free } \\
\text { movement of capital and payments. }\end{array}$ \\
\hline \multicolumn{3}{|l|}{ EU-Morocco } \\
\hline \multirow[t]{4}{*}{$\begin{array}{l}\text { Free Movement of } \\
\text { Goods }\end{array}$} & $\begin{array}{l}\text { No new customs duties on imports nor charges having } \\
\text { equivalent effect shall be introduced in trade between the } \\
\text { Community and Morocco. Customs duties and charges having equivalent } \\
\text { effect } \\
\text { applicable on import into Morocco of products originating in } \\
\text { the Community shall be abolished upon the entry into force of this } \\
\text { Agreement. }\end{array}$ & \begin{tabular}{|l|} 
There are some products that are exempt of this restriction \\
(those listed in Annexes $3,4,5$ and 6 ). Also, exceptional \\
measures of limited duration may be taken by Morocco in the \\
form of an increase or reintroduction of customs duties. These \\
measures may only concern infant industries, or certain sectors \\
undergoing restructuring or facing serious difficulties, particularly \\
where these difficulties produce major social problems.
\end{tabular} \\
\hline & $\begin{array}{l}\text { Products originating in Morocco shall be imported into the } \\
\text { Community free of customs duties and charges having } \\
\text { equivalent effect. }\end{array}$ & \\
\hline & $\begin{array}{l}\text { No new quantitative restriction on imports or measure } \\
\text { having equivalent effect shall be introduced in trade between } \\
\text { the Community and Morocco. }\end{array}$ & \\
\hline & $\begin{array}{l}\text { The two Parties shall refrain from any measures or } \\
\text { practice of an internal fiscal nature establishing, whether } \\
\text { directly or indirectly, discrimination between the products of } \\
\text { one Party and like products originating in the territory of the } \\
\text { other Party. }\end{array}$ & \\
\hline
\end{tabular}




\begin{tabular}{|c|c|c|}
\hline Restriction & How the restriction is defined & Under what condition it applies \\
\hline \multicolumn{3}{|l|}{ EU-Tunisia } \\
\hline \multirow[t]{4}{*}{$\begin{array}{l}\text { Free Movement of } \\
\text { Goods }\end{array}$} & $\begin{array}{l}\text { No new customs duties on imports nor charges having equivalent effect } \\
\text { shall be introduced in trade between the Community and Tunisia. Product } \\
\text { originating in Tunisia shall be imported into the Community free of custom } \\
\text { duties and charges having equivalent effect and without quantitative } \\
\text { restrictions or measures having equivalent effect }\end{array}$ & $\begin{array}{l}\text { This shall not preclude the retention by the Community of an } \\
\text { agricultural component on imports of the goods originating in } \\
\text { Tunisia listed in Annex } 1 \text {. The agricultural component shall reflect } \\
\text { differences between the price on the Community market of the } \\
\text { agricultural products considered as being used in the production } \\
\text { of such goods and the price of imports from third countries } \\
\text { where the total cost of the said basic products is higher in the } \\
\text { Community. The agricultural component may take the form of a } \\
\text { fixed amount or an ad valorem duty. Such differences shall be } \\
\text { replaced, where appropriate, by specific duties based on } \\
\text { tariffication of the agricultural component or by ad valorem dutie } \\
\text { Exceptional measures of limited duration which derogate from th } \\
\text { provisions of Article } 11 \text { may be taken by Tunisia in the form of an } \\
\text { increase or reintroduction of customs duties. } \\
\text { These measures may only concern infant industries, or certain } \\
\text { sectors undergoing restructuring or facing serious difficulties, } \\
\text { particularly where these difficulties produce major social problem }\end{array}$ \\
\hline & $\begin{array}{l}\text { The Community and Tunisia shall gradually implement greater liberalizati } \\
\text { of their reciprocal trade in agricultural and fishery products. }\end{array}$ & \\
\hline & $\begin{array}{l}\text { Without prejudice to the provisions of the GATT: } \\
\text { (a) no new quantitative restriction on imports or measure having equivale } \\
\text { effect shall be introduced in trade between the Community and Tunisia; } \\
\text { (b) quantitative restrictions on imports and measures having equivalent } \\
\text { effect in trade between Tunisia and the Community shall be abolished } \\
\text { upon the entry into force of this Agreement; } \\
\text { (c) the Community and Tunisia shall apply to the other's exports customs } \\
\text { neither duties or charges having equivalent effect nor quantitative } \\
\text { restrictions or measures of equivalent effect. }\end{array}$ & 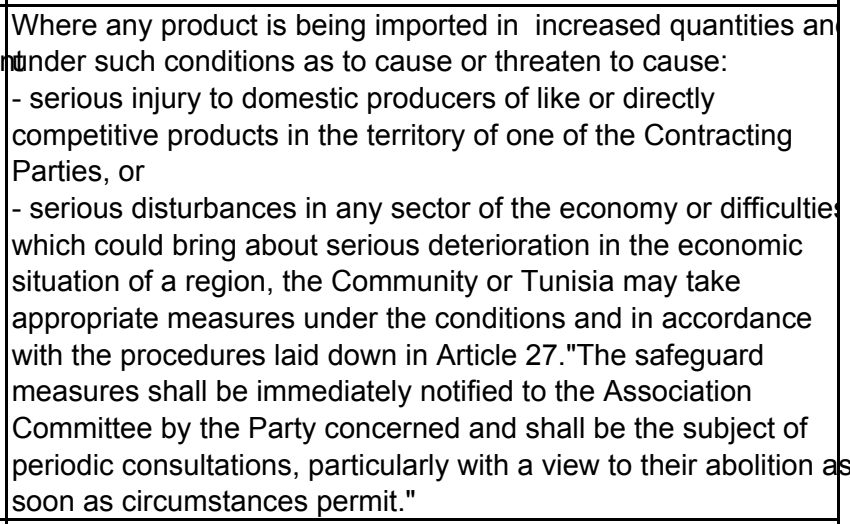 \\
\hline & $\begin{array}{l}\text { 1. The two Parties shall refrain from any measures or practice of an } \\
\text { internal fiscal nature establishing, whether directly or indirectly, } \\
\text { discrimination between the products of one Party and like products } \\
\text { originating in the territory of the other Party. } \\
\text { 2. Products exported to the territory of one of the Parties may not benefit } \\
\text { from repayment of indirect internal taxation in excess of the amount of } \\
\text { indirect taxation imposed on them directly or indirectly. }\end{array}$ & \\
\hline
\end{tabular}




\begin{tabular}{|c|c|c|}
\hline Restriction & How the restriction is defined & Under what condition it applies \\
\hline \multicolumn{3}{|l|}{ US-Jordan } \\
\hline Tariffs & $\begin{array}{l}\text { The FTA eliminates all tariff barriers on virtually all goods traded betweer } \\
\text { the United States and Jordan within ten years. }\end{array}$ & $\begin{array}{l}\text { Not every export of the United States or Jordan will qualify for } \\
\text { this duty-free treatment. The United States and Jordan has } \\
\text { agreed to eliminate existing tariffs only on "originating goods of } \\
\text { the other Party". Goods must qualify under the Rules of Origin in } \\
\text { order to take advantage of the FTA. Also, Products under specie } \\
\text { staging categories including certain alcohol and textile products, } \\
\text { generalized system of preference (GSP) exports, agriculture } \\
\text { quota-class goods, poultry, apples, and cars will experience } \\
\text { either an accelerated reduction of tariffs or a delay in reduction. }\end{array}$ \\
\hline Intellectual property & $\begin{array}{l}\text { Jordan has agreed to accede to: Articles 1-14 of the World Intellectual } \\
\text { Property Organization's (WIPO) Copyright Treaty; Articles 1-23 of the } \\
\text { WIPO Performances and Phonographs Treaty; Articles 1-22 of the } \\
\text { International Convention for the Protection of New Varieties of Plants; } \\
\text { Articles 1-6 of the Joint Recommendation Concerning Provisions on the } \\
\text { Protection of Well-Known Marks; Patent Cooperation Treaty (1984); } \\
\text { Protocol Relating to the Madrid Agreement Concerning the International } \\
\text { Registrations of Marks (1989) }\end{array}$ & $\begin{array}{l}\text { The United States and Jordan have agreed to take measures } \\
\text { related to certain regulated products, particularly in the area of } \\
\text { "approving the marketing of pharmaceuticals or agricultural } \\
\text { chemical products that utilize new chemical entities" and } \\
\text { protecting the information against disclosure and unfair } \\
\text { commercial use. }\end{array}$ \\
\hline Services & $\begin{array}{l}\text { Liberalization of bilateral trade in services between the United States and } \\
\text { Jordan. With the liberalization of trade in services, United States } \\
\text { companies will have greater access to Jordanian service industries, } \\
\text { especially tourism, transportation, health, financial, education, } \\
\text { environmental, business, communications, distribution and } \\
\text { recreational/cultural services. }\end{array}$ & \\
\hline Rules of Origin & $\begin{array}{l}\text { The FTA defines originating goods as having three components: a } \\
\text { qualitative definition of origin ("the "wholly obtained"/"substantial } \\
\text { transformation" tests), a quantitative definition of origin (the 35\% domestio } \\
\text { content requirement) and a direct transport requirement. }\end{array}$ & $\begin{array}{l}\text { The direct transport requirement and permitted exceptions are } \\
\text { discussed in Chapter } 9 \text { of the Rules of Origin. not significant) }\end{array}$ \\
\hline
\end{tabular}




\begin{tabular}{|c|c|c|}
\hline Restriction & How the restriction is defined & Under what condition it applies \\
\hline \multicolumn{3}{|l|}{ US-Chile } \\
\hline Tariffs eliminations & $\begin{array}{l}\text { Neither Party may increase any existing customs duty, or adopt any } \\
\text { customs duty, on an originating good. Each Party shall progressively } \\
\text { eliminate its customs duties on originating goods. 3. The United States } \\
\text { shall eliminate customs duties on any non-agricultural originating } \\
\text { goods that, after the date of entry into force of this Agreement, are } \\
\text { designated as articles eligible for duty-free treatment under the U.S. } \\
\text { Generalized System of Preferences, effective from the date of such } \\
\text { designation. }\end{array}$ & $\begin{array}{l}\text { a Party may:(a) raise a customs duty back to the level } \\
\text { established in its Schedule to Annex } 3.3 \text { following a unilateral } \\
\text { reduction; or (b) maintain or increase a customs duty as } \\
\text { authorized by the Dispute Settlement Body of the WTO. }\end{array}$ \\
\hline $\begin{array}{l}\text { Drawback and Duty } \\
\text { Deferral Programs }\end{array}$ & $\begin{array}{l}\text { Neither Party may refund the amount of customs duties paid, or waive or } \\
\text { reduce the amount of customs duties owed, on a good imported into its } \\
\text { territory. Neither Party may, on condition of export, refund, waive, or } \\
\text { reduce:(a) an antidumping or countervailing duty; (b) a premium offered of } \\
\text { collected on an imported good arising out of any tendering system in } \\
\text { respect of the administration of quantitative import restrictions, tariff rate } \\
\text { quotas, or tariff preference levels; or (c) customs duties paid or owed on } \\
\text { good imported into its territory and substituted by an identical or similar } \\
\text { good that is subsequently exported to the territory of the other Party }\end{array}$ & $\begin{array}{l}\text { This applies on condition that the good is:(a) subsequently } \\
\text { exported to the territory of the other Party; (b) used as a materia } \\
\text { in the production of another good that is subsequently exported } \\
\text { oto the territory of the other Party; or (c) substituted by an identica } \\
\text { or similar good used as a material in the production of another } \\
\text { good that is subsequently exported to the territory of the other } \\
\text { Party. }\end{array}$ \\
\hline $\begin{array}{l}\text { Import and Export } \\
\text { Restrictions }\end{array}$ & $\begin{array}{l}\text { Neither Party may adopt or maintain any prohibition or restriction on the } \\
\text { importation of any good of the other Party or on the exportation or sale for } \\
\text { export of any good destined for the territory of the other Party }\end{array}$ & $\begin{array}{l}\text { This prohibit any country form adopting (a) export and import } \\
\text { price requirements, except as permitted in enforcement of } \\
\text { countervailing and antidumping orders and undertakings; (b) } \\
\text { import licensing conditioned on the fulfillment of a performance } \\
\text { requirement; or (c) voluntary export restraints not consistent with } \\
\text { Article VI of GATT 1994, as implemented under Article } 18 \text { of the } \\
\text { SCM Agreement and Article } 8.1 \text { of the AD Agreement. }\end{array}$ \\
\hline Export taxes & $\begin{array}{l}\text { Neither Party may adopt or maintain any duty, tax, or other charge on the } \\
\text { export of any good to the territory of the other Party }\end{array}$ & $\begin{array}{l}\text { Applies always, unless such duty, tax, or charge is adopted or } \\
\text { maintained on any such good when destined for domestic } \\
\text { consumption. }\end{array}$ \\
\hline Textile and Apparel & $\begin{array}{l}\text { If, as a result of the elimination of a duty provided for in this Agreement, a } \\
\text { textile or apparel good benefiting from preferential tariff treatment under } \\
\text { this Agreement is being imported into the territory of a Party in such } \\
\text { increased quantities, in absolute terms or relative to the domestic market } \\
\text { for that good, and under such conditions as to cause serious damage, or } \\
\text { actual threat thereof, to a domestic industry producing a like or directly } \\
\text { competitive good, the importing Party may, to the extent and for such time } \\
\text { as may be necessary to prevent or remedy such damage and to facilitate } \\
\text { adjustment, take emergency action, consisting of an increase in the rate } \\
\text { duty on the good to a level not to exceed the lesser of:(a) the most-favore } \\
\text { nation (MFN) applied rate of duty in effect at the time the action is taken; } \\
\text { and (b) the MFN applied rate of duty in effect on the date of entry into for } \\
\text { of this Agreement. }\end{array}$ & $\begin{array}{l}\text { The importing Party may take an emergency action under this } \\
\text { Article only following an investigation by its competent authoritie } \\
\text { Also, (a) no emergency action may be maintained for a period } \\
\text { exceeding three years; (b) no emergency action may be taken or } \\
\text { maintained beyond the period ending eight years after duties on } \\
\text { good have been eliminated pursuant to this Agreement; (c) no } \\
\text { gemergency action may be taken by an importing Party against } \\
\text { any particular good of the other Party more than once; and (d) o } \\
\text { termination of the action, the good will return to duty-free status. } \\
\text { d- }\end{array}$ \\
\hline Intellectual Property & $\begin{array}{l}\text { Both parties need to accede or ratify to a series of patent and Intellectual } \\
\text { property treaties }\end{array}$ & $\begin{array}{l}\text { Each Party may, but shall not be obliged to, implement in its } \\
\text { domestic law more extensive protection than is required by this } \\
\text { Agreement provided that such protection does not contravene } \\
\text { the provisions of this Agreement. }\end{array}$ \\
\hline
\end{tabular}




\begin{tabular}{|c|c|c|}
\hline Restriction & How the restriction is defined & Under what condition it applies \\
\hline \multicolumn{3}{|c|}{ IMF (structural conditionality) } \\
\hline \begin{tabular}{|l|} 
Trade Policy \\
(general)
\end{tabular} & $\begin{array}{l}\text { Complete equalization of excises on all domestic, imported goods and } \\
\text { Eliminate reference prices for all imports and remove exchange controls }\end{array}$ & \\
\hline \multicolumn{3}{|l|}{ Indonesia. } \\
\hline \multirow[t]{9}{*}{$\begin{array}{l}\text { Stand-By Agreement } \\
1998\end{array}$} & $\begin{array}{l}\text { Eliminate all restrictions on foreign investment in palm oil plantations, retail } \\
\text { and wholesale trade and establish a level playing field in the import and } \\
\text { distribution of essential food items between BULOG and private sector } \\
\text { participants. }\end{array}$ & \\
\hline & $\begin{array}{l}\text { Eliminate subsidies on sugar, wheat flour, corn, soybean meal and } \\
\text { fishmeal. }\end{array}$ & \\
\hline & $\begin{array}{l}\text { Phase out local content program for motor vehicles and abolish local } \\
\text { content regulations on dairy products. }\end{array}$ & \\
\hline & \begin{tabular}{|l|l} 
Discontinue budgetary and extra budgetary support and privileges to IPTN \\
(Nusantara Aircraft Industry) projects.
\end{tabular} & \\
\hline & $\begin{array}{l}\text { Reduce by } 5 \text { percentage points tariffs on items currently subject to tariffs } \\
\text { of } 15 \text { to } 25 \text { percent. Tariff reduction on non-food agricultural, chemical, } \\
\text { steel-metal, and fishery products }\end{array}$ & \\
\hline & $\begin{array}{l}\text { Phase out remaining quantitative import restrictions and other non-tariff } \\
\text { barriers. }\end{array}$ & \\
\hline & $\begin{array}{l}\text { Abolish export taxes on leather, cork, ores and waste aluminum products } \\
\text { and Reduce export taxes on logs, sawn timber, rattan and minerals }\end{array}$ & \\
\hline & Eliminate all other export restrictions. & \\
\hline & $\begin{array}{l}\text { Take effective action to allow free competition in: } \\
\text { (i) importation of wheat, wheat flour, soybeans and garlic; } \\
\text { (ii) sale or distribution of flour; and } \\
\text { (iii) importation and marketing of sugar. }\end{array}$ & \\
\hline \multicolumn{3}{|c|}{ 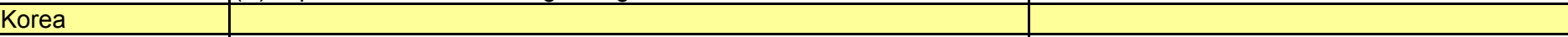 } \\
\hline $\begin{array}{l}\text { Stand-By } \\
\text { Arrangement } \\
\text { December 5, } 1997 \\
\text { Economic Program }\end{array}$ & $\begin{array}{l}\text { 1) Eliminate trade-related subsidies; } \\
\text { 2) Eliminate restrictive import licensing; } \\
\text { 3) Eliminate the import diversification program; and } \\
\text { 4) Streamline and improve the transparency of the import certificatiol }\end{array}$ & \\
\hline \multicolumn{3}{|l|}{ Turkey } \\
\hline \begin{tabular}{|l|} 
stand-by \\
arrangement with the \\
International \\
Monetary Fund. \\
2001
\end{tabular} & $\begin{array}{l}\text { Agriculture reform program : removal of credit subsidies from state banks } \\
\text { reform the sugar market and liberalization of the tobacco sector }\end{array}$ & \\
\hline \multicolumn{3}{|l|}{ Ethiopia } \\
\hline \begin{tabular}{l|} 
Letter of Intent, \\
Memorandum of \\
Economic and \\
Financial Policies, \\
and Technical \\
Memorandum of \\
Understanding 2001
\end{tabular} & $\begin{array}{l}\text { Cease price verification on all nonagricultural commodity exports and non } \\
\text { cofee agricultural exports for which verifiable international prices are not } \\
\text { readily available. For other agricultural exports, except coffee, replace ex } \\
\text { ante price verification with ex post audit, and, for coffee, replace the } \\
\text { verification of a single point price with the verification of a range of prices } \\
\text { for each variety; Reduce import tariffs and liberalize the payments and } \\
\text { exchange regulations for foreign trade in goods and services }\end{array}$ & \\
\hline
\end{tabular}




\begin{tabular}{|l|l|l|}
\hline \multicolumn{1}{|c|}{ Restriction } & \multicolumn{1}{|c|}{ How the restriction is defined } & \multicolumn{1}{|c|}{ Under what condition it applies } \\
\hline & $\begin{array}{l}\text { (i) removing restrictions on foreign suppliers'/partners' credit and on } \\
\text { importing inputs without payment from foreign collaborators, as well as on } \\
\text { other implicit forms of credit not involving formal loan agreements; (ii) } \\
\text { allowing all exporters of manufactures (including of agro-processed } \\
\text { products) to obtain foreign commercial borrowing; (iii) easing the } \\
\text { constraints on debt-equity ratios for exporters by allowing the NBE to } \\
\text { authorize exporters to exceed the limit of 60/40 that currently obtains; and } \\
\text { (iv) allowing banks to open import letters of credit for exporters with } \\
\text { confirmed letters. }\end{array}$ & \\
\hline & $\begin{array}{l}\text { Eliminate price and quality preferences for domestic input suppliers and } \\
\text { further improve the duty drawback and exemption schemes }\end{array}$ & \\
\hline Mozambique & $\begin{array}{l}\text { Rationalize import tariffs. Lower the top import tariff rate from 35 percent t } \\
\text { Enhanced Structural }\end{array}$ & \\
Adjustment Facility \\
1998-2000
\end{tabular}

\section{Sources:}

WTO: World Bank (2002) "Development, Trade and WTO: A Handbook" Edited by Bernard Hoekman, Aaditya Mattoo and Philip English

NAFTA: http://www.nafta-sec-alena.org/DefaultSite/home/index_e.aspx

EU http://europa.eu.int/pol/comm/index_en.htm

EU-Morocco http://europa.eu.int/eur-lex/pri/en/oj/dat/2000/l_070/l_07020000318en00020190.pdf

EU-Tunisia http://europa.eu.int/eur-lex/pri/en/oj/dat/1998// 097// 09719980330en00020174.pdf

US-Jordan. http://www.jordanusfta.com/

US-Chile.http://www.ustr.gov/new/fta/Chile/final/03.market\%20access.PDF

IMF http://www.imf.org/external/np/pdr/cond/2001/eng/trade/index.htm, http://www.imf.org/external/np/pdr/cond/2001/eng/trade/index.htm

Indonesia. http://www.imf.org/external/np/loi/041098.pdf

Korea. http://www.imf.org/external/np/oth/korea.htm \& http://www.imf.org/external/np/loi/122497.htm\#box5

Turkey. http://www.imf.org/external/np/loi/2001/tur/02/index.htm Letter of Intent. May 2001.

EThiopia. http://www.imf.org/external/np/pfp/eth/etp.htm, http://www.imf.org/external/pubs/ft/scr/1999/cr9998.pdf

Mozambique. http://www.imf.org/external/np/pfp/mozam/moztap.htm 